\title{
Comparative toxicogenomic responses of mercuric and methyl-mercury
}

\author{
Matthew K McElwee', Lindsey A Ho², Jeff W Chou ${ }^{3,4}$, Marjolein V Smith² and Jonathan H Freedman ${ }^{*}$
}

\begin{abstract}
Background: Mercury is a ubiquitous environmental toxicant that exists in multiple chemical forms. A paucity of information exists regarding the differences or similarities by which different mercurials act at the molecular level.

Results: Transcriptomes of mixed-stage C. elegans following equitoxic sub-, low- and high-toxicity exposures to inorganic mercuric chloride $\left(\mathrm{HgCl}_{2}\right)$ and organic methylmercury chloride $(\mathrm{MeHgCl})$ were analyzed. In C. elegans, the mercurials had highly different effects on transcription, with $\mathrm{MeHgCl}$ affecting the expression of significantly more genes than $\mathrm{HgCl}_{2}$. Bioinformatics analysis indicated that inorganic and organic mercurials affected different biological processes. RNAi identified 18 genes that were important in C. elegans response to mercurial exposure, although only two of these genes responded to both mercurials. To determine if the responses observed in $C$. elegans were evolutionarily conserved, the two mercurials were investigated in human neuroblastoma (SK-N-SH), hepatocellular carcinoma (HepG2) and embryonic kidney (HEK293) cells. The human homologs of the affected C. elegans genes were then used to test the effects on gene expression and cell viability after using siRNA during $\mathrm{HgCl}_{2}$ and $\mathrm{MeHgCl}$ exposure. As was observed with C. elegans, exposure to the $\mathrm{HgCl}_{2}$ and $\mathrm{MeHgCl}$ had different effects on gene expression, and different genes were important in the cellular response to the two mercurials.

Conclusions: These results suggest that, contrary to previous reports, inorganic and organic mercurials have different mechanisms of toxicity. The two mercurials induced disparate effects on gene expression, and different genes were important in protecting the organism from mercurial toxicity.
\end{abstract}

Keywords: C. elegans, Inorganic mercury, Organic mercury, Methylmercury, Transcriptome, Metal toxicity

\section{Background}

Mercury is a ubiquitous environmental contaminant that exists as either an organic or inorganic species that undergoes complex cycling in the environment and in vivo. Humans are exposed to various forms of inorganic mercury including elemental mercury $\left(\mathrm{Hg}^{0}\right)$, mercury salts and ionic mercury $\left(\mathrm{Hg}^{+}\right.$or $\left.\mathrm{Hg}^{2+}\right)$. Elemental mercury has long been used as a principal component of dental amalgams, resulting in the exposure of individuals wearing amalgams and dental professionals to mercury vapor. Other occupational exposures to mercury vapor include workers in chloralkali plants, fluorescent lamp factories and artisanal gold mines [1,2]. Exposure to mercury vapor can result in tremors; deficits in

\footnotetext{
* Correspondence: freedma1@niehs.nih.gov

'Laboratory of Toxicology and Pharmacology, National Institute of Environmental Health Sciences, NIH, 111 T.W Alexander Drive, Research Triangle Park, P.O. Box 12233, 27709 Durham, NC, USA

Full list of author information is available at the end of the article
}

information processing speed, psychomotor speed and manual dexterity; psychological disturbances; and has been associated with Alzheimer's disease [3,4]. The kidney is also a primary site of accumulation and toxicity of inorganic mercury. Environmental exposure to inorganic mercury is associated with an increase in mortality from kidney disease [2,5].

Inorganic mercury from natural and anthropogenic sources is converted to methylmercury. Methylmercury biomagnifies, so that animals at the top of the food chain have methylmercury levels that are orders of magnitude higher than those at the bottom [6]. Humans are exposed to methylmercury through fish consumption. It is estimated that $7 \%$ of U.S. women of childbearing age have levels of methylmercury that exceed the U.S. EPA reference dose of $0.1 \mu \mathrm{g} / \mathrm{kg}$ body weight/day [7]. Methylmercury poisoning outbreaks in the 1950s and 1960s in the area surrounding Minamata Bay in Japan resulted in paresthesia, ataxia, loss of vision, and death in adults [8]. What was particularly 
striking, however, was the sensitivity of the in utero life stage to methylmercury exposure. Mothers with no overt toxicity gave birth to children with gross cognitive and anatomical defects [9]. A large epidemiological study investigating the effects of prenatal mercury exposure in populations that consume large amounts of seafood found a significant correlation between mothers' mercury levels during gestation and cognitive deficits in children [10,11].

Previous research suggested that the inorganic mercurial, $\mathrm{HgCl}_{2}$, and the organic mercurial, methylmercury chloride $(\mathrm{MeHgCl})$, had similar mechanisms of toxicity. It has been hypothesized that organic mercury is converted to the inorganic species and that the latter is the active form of the metal. Both $\mathrm{HgCl}_{2}$ and $\mathrm{MeHgCl}$ cause oxidative stress [12,13]. It is believed that oxidative stress is caused by the depletion of glutathione and other antioxidants, since neither mercurial is redox active in vivo [14]. Other proposed mechanisms of $\mathrm{HgCl}_{2}$ and $\mathrm{MeHgCl}$ toxicity include microtubule disruption [15,16], inhibition of mitochondrial function, and disruption of intracellular calcium levels [17-20]. Microarray studies examining the effects of $\mathrm{HgCl}_{2}$ or $\mathrm{MeHgCl}$ on gene expression found differential expression of genes involved in the oxidative stress response, protein degradation, mitochondrial dysfunction, endoplasmic reticulum stress and phase II metabolism [21-23].

The results of previous toxicity studies suggest that $\mathrm{HgCl}_{2}$ and $\mathrm{MeHgCl}$ act via similar mechanisms [24]. The few studies that have directly compared the effects of inorganic and methylmercury also suggest that the two mercurials have similar mechanisms of action. Freitas, et al. found that both inorganic and methylmercury inhibit $\mathrm{Ca}^{2+}$-ATPase and disrupted $\mathrm{Ca}^{2+}$ transport in brain microsomes [25]. Both mercurials stimulated release of noradrenaline from rat hippocampal slices and had similar effects on inflammatory cytokine release in lipopolysaccharide-stimulated peripheral blood mononuclear cells [26,27].

In the present study, whole-genome microarrays were used to assess the effects of sub-, low- and high-toxicity concentrations of $\mathrm{HgCl}_{2}$ and $\mathrm{MeHgCl}$ on the C. elegans transcriptome. To define the genes that are critical in the $C$. elegans response to mercurial exposure, RNA interference (RNAi) was used to assess the effect of gene knockdown on C. elegans growth during mercurial exposure. Of the 599 genes tested, decreased expression of 18 genes significantly affected $C$. elegans growth in response to either mercurial. Only two of these, however, significantly impacted growth during both $\mathrm{HgCl}_{2}$ and $\mathrm{MeHgCl}$ exposures. The effects of $\mathrm{HgCl}_{2}$ and $\mathrm{MeHgCl}$ on the steady-state mRNA levels of nine human homologs of $C$. elegans genes critical in the mercurial response were determined in human neuroblastoma (SK-N-SH), hepatocellular carcinoma (HepG2), and embryonic kidney
(HEK293) cells. As was observed in C. elegans, $\mathrm{HgCl}_{2}$ and $\mathrm{MeHgCl}$ produced unique responses on gene expression and different genes were critical in the cellular response. The current results demonstrate that inorganic and methylmercury differentially affect gene expression and that different genes are critical in the cellular response to the two mercurials. This suggests that, contrary to previous reports, inorganic and organic mercurials have unique mechanisms of action.

\section{Results}

\section{Genes differentially expressed in response to mercurial exposure}

The effects of mercurials on gene expression in C. elegans were assessed after exposure to sub-, low- and hightoxicity concentrations of $\mathrm{HgCl}_{2}$ and $\mathrm{MeHgCl}$. Sub-, low- and high-toxicity concentrations were determined based on a previous study that compared the toxicity of $\mathrm{HgCl}_{2}$ and $\mathrm{MeHgCl}$ on $C$. elegans growth, reproduction, feeding, and locomotion [28]. The effects of mercurials on the steady-state mRNA levels of the C. elegans stressresponse genes; gcs-1 ( $\gamma$-glutamylcysteine synthetase), gst-38 (glutathione $S$-transferase), and heat shock protein genes $h s p-16.2$ and $h s p-70$; were also assessed [28]. The population distribution of 7,000 nematodes was determined for each mercurial exposure prior to RNA isolation. No treatment groups had a population distribution different from untreated control. This ensured that differences in gene expression were not the result of changes in the number of $C$. elegans at any individual life stage (Additional file 1: Figure S3).

A total of 3,207 genes were significantly, differentially expressed among the six exposure conditions (fold-change $\geq$ $2, \mathrm{p}<0.01)$. Exposure to increasing concentrations of both $\mathrm{HgCl}_{2}$ and $\mathrm{MeHgCl}$ resulted in increasing numbers of differentially expressed genes (DEGs). At each level of toxicity, however, $\mathrm{MeHgCl}$ exposure produced a greater number of DEGs (Table 1).

The five genes that had the largest increase or decrease in expression for each treatment condition are presented in Table 2. All DEGs are presented in Additional file 2: Table S4. Figure 1 shows the similarity among commonly up- and down-regulated genes at low- and high-toxicity mercurial exposures. Very few genes were similarly affected by both $\mathrm{HgCl}_{2}$ and $\mathrm{MeHgCl}$ exposures. The only genes whose expression was affected at low- and high-toxicity exposures to both mercurials were ugt-21, UDP-glucuronosyl transferase, and C15B12.8, an uncharacterized gene with high similarity to sarcosine oxidase. There were 24 up-regulated and eight down-regulated genes after exposure to each of the three $\mathrm{MeHgCl}$ concentrations (Table 3). Among the three $\mathrm{HgCl}_{2}$ exposures the only up-regulated gene was metallothionein-2 (mtl-2). Conversely, $m t l-2$ was down-regulated in response to all 
Table 1 Effects of Mercurials on Gene Expression in C. elegans

\begin{tabular}{|c|c|c|c|c|}
\hline \multirow[b]{2}{*}{ Toxicity } & \multicolumn{2}{|c|}{$\mathrm{HgCl}_{2}$} & \multicolumn{2}{|c|}{$\mathrm{MeHgCl}$} \\
\hline & Concentration $(\mu \mathrm{M})$ & Gene number & Concentration $(\mu \mathrm{M})$ & Gene number \\
\hline sub & 2.0 & $\begin{array}{c}8 \\
(8 \uparrow, 0 \downarrow)\end{array}$ & 0.75 & $\begin{array}{c}44 \\
(35 \uparrow, 9 \downarrow)\end{array}$ \\
\hline low & 7.5 & $\begin{array}{c}74 \\
(68 \uparrow, 6 \downarrow)\end{array}$ & 2.0 & $\begin{array}{c}419 \\
(247 \uparrow, 172 \downarrow)\end{array}$ \\
\hline \multirow{2}{*}{ high } & \multirow{2}{*}{20} & 403 & \multirow{2}{*}{7.5} & 2,791 \\
\hline & & $(316 \uparrow, 87 \downarrow)$ & & $(1,604 \uparrow, 1,187 \downarrow)$ \\
\hline
\end{tabular}

Number of genes showing increased $(\uparrow)$ or decreased $(\downarrow)$ steady state mRNA levels.

$\mathrm{MeHgCl}$ exposures. qRT-PCR confirmed these microarray results, showing that $m t l-2$ was up-regulated by all $\mathrm{HgCl}_{2}$ treatments and down-regulated by $\mathrm{MeHgCl}$. Similarly, $m t l-1$ was up-regulated at sub- and low-toxicity $\mathrm{HgCl}_{2}$ exposures, and down-regulated in low-toxicity $\mathrm{MeHgCl}$ exposure (Figure 2).

Principal components analysis (PCA) and hierarchical clustering were performed to determine the reproducibility of the mercurial-induced changes in the transcriptome, as well as visualize global effects of $\mathrm{HgCl}_{2}$ and $\mathrm{MeHgCl}$ on C. elegans gene expression. PCA with all genes showed tight spatial positioning of replicates indicating high experimental reproducibility (Figure 3A). The first principal component, which accounted for $33 \%$ of the variation in the data, segregated by mercurial treatments, while the second principal component, which accounted for $22 \%$ of the variation, segregated by toxicity treatments or concentration. PCA using only differentially expressed genes yielded similar results, but the first two principal components accounted for $85 \%$ of the variability (Figure $3 \mathrm{~B}$ ).

Consistent with the PCA, the hierarchical clustering found high reproducibility in transcriptome changes for

Table 2 Most significantly affected mercurial-responsive genes

\begin{tabular}{|c|c|c|c|c|c|c|c|c|}
\hline \multicolumn{9}{|c|}{$\mathrm{MeHgCl}$} \\
\hline Sequence name & Gene name & Fold change & Sequence name & Gene name & Fold change & Sequence name & Gene name & Fold change \\
\hline \multicolumn{3}{|c|}{$0.75 \mu \mathrm{M}$} & \multicolumn{3}{|c|}{$2 \mu \mathrm{M}$} & \multicolumn{3}{|c|}{$7.5 \mu \mathrm{M}$} \\
\hline Y32G9A.1 & gst-37 & 9.4 & Y32G9A.1 & gst-37 & 77 & Y32G9A.1 & gst-37 & 100 \\
\hline $\mathrm{Y} 1 \mathrm{H} 11.2$ & gst-35 & 8.5 & F11A5.12 & stdh-2 & 24 & F11A5.12 & \multirow[t]{3}{*}{$s t d h-2$} & 98 \\
\hline C29F3.1 & ech-1 & 4.2 & $\mathrm{Y} 1 \mathrm{H} 11.2$ & gst-35 & 22 & W08E12.2 & & 69 \\
\hline F35E12.5 & & 4.0 & H23L24.5 & pme-4 & 22 & F22E5.6 & & 68 \\
\hline M199.7 & & 4.0 & Y43F8C.1 & \multirow[t]{4}{*}{$n / p-25$} & 19 & Y53F4B.35 & \multirow[t]{2}{*}{ gst-31 } & 67 \\
\hline F37B1.8 & gst-19 & -4.2 & $\mathrm{~T} 26 \mathrm{H} 2.5$ & & -11 & C13A2.4 & & -99 \\
\hline T08G5.10 & $m t-2$ & -3.2 & Y32B12A.1 & & -10 & F46B3.17 & \multirow[t]{4}{*}{ col-163 } & -97 \\
\hline $\mathrm{T} 26 \mathrm{H} 2.5$ & & -3.1 & R05D8.11 & & -7.8 & R05D8.11 & & -93 \\
\hline C05E4.14 & srh-2 & -2.2 & F37B1.8 & gst-19 & -5.9 & F53F4.7 & & -91 \\
\hline ZK666.6 & clec-160 & -2.1 & E03H12.3 & clec-176 & -5.4 & $\mathrm{~T} 26 \mathrm{H} 2.5$ & & -88 \\
\hline \multicolumn{9}{|c|}{$\mathrm{HgCl}_{2}$} \\
\hline \multicolumn{3}{|c|}{$2 \mu \mathrm{M}$} & \multicolumn{3}{|c|}{$7.5 \mu \mathrm{M}$} & \multicolumn{3}{|c|}{$20 \mu \mathrm{M}$} \\
\hline T08G5.10 & $m t \mid-2$ & 3.1 & T08G5.10 & $m t-2$ & 42 & F22E10.4 & pgp-15 & 84 \\
\hline K01D12.1 & & 2.1 & T08G5.1 & & 29 & C15B12.8 & & 43 \\
\hline M02D8.4 & asns-2 & 2.1 & K11G9.6 & $m t-1$ & 12 & C45B2.3 & & 25 \\
\hline F07C4.10 & & 2.1 & F56A4.2 & & 11 & $\mathrm{C} 17 \mathrm{H} 1.8$ & & 21 \\
\hline \multirow[t]{6}{*}{$\mathrm{F} 15 \mathrm{H} 10.8$} & & 2.1 & Y39B6A.1 & & 7.9 & Y70C5C.2 & clec-9 & 21 \\
\hline & & & T25D10.2 & & -3.8 & K03B8.11 & & -6.0 \\
\hline & & & F49H6.12 & & -3.7 & T15B7.3 & col-143 & -5.2 \\
\hline & & & F29A7.7 & clec-20 & -3.7 & Y57A10C.1 & & -5.2 \\
\hline & & & F14F8.4 & srz-103 & -2.9 & K05F6.4 & & -5.2 \\
\hline & & & C43G2.2 & bicd-1 & -2.8 & F54E7.5 & $s d z-21$ & -5.1 \\
\hline
\end{tabular}



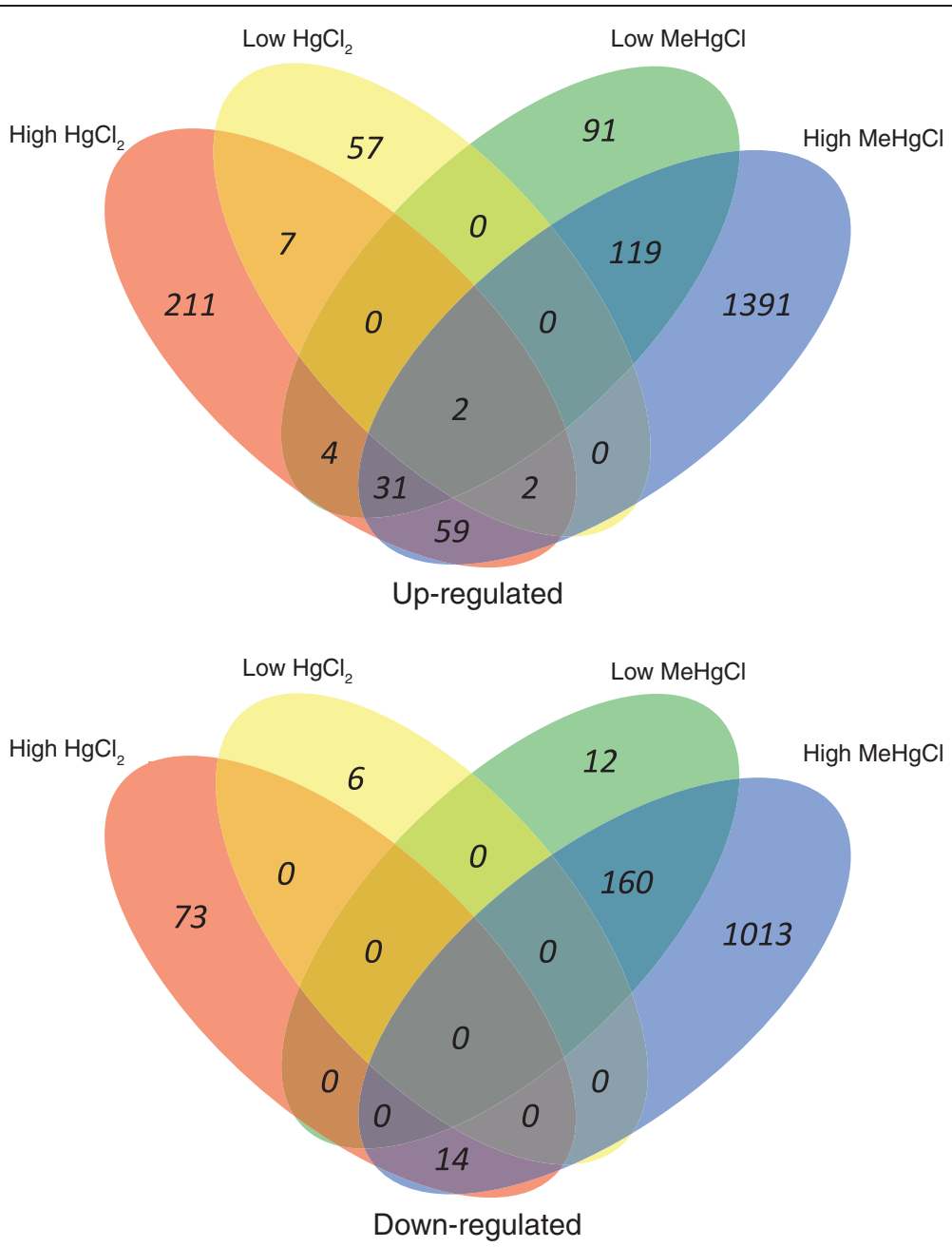

Figure 1 Venn diagrams of up-regulated and down-regulated genes following low- and high-toxicity $\mathrm{HgCl}_{2}$ and $\mathrm{MeHgCl}$ exposures.

Venn diagram indicating which genes are commonly and uniquely up- or down-regulated between the low- and high-toxicity $\mathrm{HgCl}_{2}$ and MeHgCl exposures.

each of the mercurial treatments, indicating high quality data (Figure 4). Hierarchical clustering analysis of differentially expressed genes also found that the two mercurials had different effects on the C. elegans transcriptome (Figure 4). Gene expression profiles for sub- and lowtoxicity treated nematodes were similar for the individual mercurials. The effect of sub- and low-toxicity $\mathrm{HgCl}_{2}$ treatments on gene transcription was nearly opposite to the effect of sub- and low-toxicity $\mathrm{MeHgCl}$ treatments. Genes up-regulated by $\mathrm{HgCl}_{2}$ sub- and low-toxicity treatments were down-regulated by $\mathrm{MeHgCl}$ treatments, and genes down-regulated by sub- and low-toxicity $\mathrm{HgCl}_{2}$ treatments were up-regulated by sub- and low-toxicity $\mathrm{MeHgCl}$ treatments (Figure 4). The gene expression profiles for the high-toxicity exposures for $\mathrm{HgCl}_{2}$ and $\mathrm{MeHgCl}$ were both dissimilar from the other treatments. There were, however, a small number of common differentially expressed genes at the highest $\mathrm{HgCl}_{2}$ and $\mathrm{MeHgCl}$ concentrations. These may represent a general stress response that could be induced as the nematodes begin to succumb to mercurial toxicity. The PCA and hierarchical clustering results suggest that changes in transcription are dictated largely by the type of mercurial.

Microarray results were further analyzed to identify biological processes affected by the mercurials. Differentially expressed genes were examined for enrichment in Gene Ontologies. Table 4 lists the significantly enriched GO biological processes for each mercurial treatment. For genes affected by high-toxicity $\mathrm{HgCl}_{2}$ and $\mathrm{MeHgCl}$ exposures, there was an enrichment of genes involved in lipid glycosylation and body morphogenesis. Aside from this difference, there was very little overlap in enriched GO processes between mercurials. There was not a significant enrichment of genes down-regulated in low-toxicity $\mathrm{HgCl}_{2}$ exposures. The lack of overlap in enriched GO terms further indicated that $\mathrm{HgCl}_{2}$ and $\mathrm{MeHgCl}$ had 
Table 3 Differentially expressed C. elegans genes following $\mathrm{MeHgCl}$ exposures

\begin{tabular}{|c|c|c|c|c|}
\hline \multirow{2}{*}{$\begin{array}{l}\text { Sequence } \\
\text { name }\end{array}$} & \multirow{2}{*}{$\begin{array}{l}\text { Gene } \\
\text { name }\end{array}$} & \multicolumn{3}{|c|}{ MeHgCl concentration $(\mu \mathrm{M})$} \\
\hline & & 0.75 & 2.0 & 7.5 \\
\hline B0507.8 & & 2.3 & 2.2 & 2.0 \\
\hline B0554.6 & dod-20 & 2.3 & 3.3 & 8.5 \\
\hline C15B12.8 & & 2.7 & 14 & 14 \\
\hline C33A12.6 & ugt-21 & 2.1 & 3.7 & 3.5 \\
\hline $\mathrm{C} 34 \mathrm{H} 4.1$ & & 2.6 & 6.6 & 13 \\
\hline F07E5.9 & & 2.3 & 4.3 & 4.7 \\
\hline F11A5.12 & stdh-2 & 3.8 & 24 & 98 \\
\hline F11D11.3 & & 2.5 & 6.5 & 33 \\
\hline F15B9.1 & far-3 & 2.2 & 3.8 & 6.3 \\
\hline F35E12.5 & & 4.0 & 17 & 32 \\
\hline F37B1.2 & gst-12 & 2.1 & 7.0 & 39 \\
\hline F53B2.2 & tsp-4 & 2.2 & 5.3 & 15 \\
\hline F56D5.3 & & 2.2 & 5.0 & 7.0 \\
\hline K08F4.7 & gst-4 & 2.4 & 4.4 & 10 \\
\hline M199.7 & & 4.0 & 4.9 & 4.1 \\
\hline T04H1.9 & $t b b-6$ & 2.4 & 9.6 & 36 \\
\hline W06H8.2 & & 2.9 & 9.9 & 29 \\
\hline Y1H11.2 & gst-35 & 2.9 & 9.9 & 29 \\
\hline Y32G9A.1 & gst-37 & 9.4 & 77 & 100 \\
\hline Y39G10AR.6 & ugt-31 & 2.1 & 4.4 & 5.7 \\
\hline Y43F8C.1 & $n / p-25$ & 3.5 & 19 & 17 \\
\hline Y45F10B.1 & tsp-5 & 2.1 & 5.4 & 17 \\
\hline ZC239.14 & & 2.5 & 4.4 & 11 \\
\hline ZK697.6 & gst-21 & 2.9 & 4.2 & 2.6 \\
\hline C05E4.14 & srh-2 & -2.2 & -3.4 & -4.5 \\
\hline C11E4.7 & & -2.1 & -3.4 & -6.9 \\
\hline C15A11.7 & & -2.1 & -3.9 & -6.7 \\
\hline F11A5.9 & & -2.1 & -2.8 & -8.3 \\
\hline F37B1.8 & gst-19 & -4.2 & -5.9 & -5.4 \\
\hline T08G5.10 & $m t-2$ & -3.2 & -3.5 & -3.5 \\
\hline $\mathrm{T} 26 \mathrm{H} 2.5$ & & -3.1 & -11 & -88 \\
\hline ZK666.6 & clec-60 & -2.1 & -3.2 & -3.0 \\
\hline
\end{tabular}

different effects on gene expression and affect unique biological processes.

\section{Co-expressed genes}

The EPIG analysis tool identified gene expression patterns that differed between the two mercurials and the treatment concentrations and then categorized genes with similar patterns of transcription [29]. It has been proposed that genes with similar expression patterns across different treatment conditions may be co-regulated or involved in related biological processes. Using data for all probes

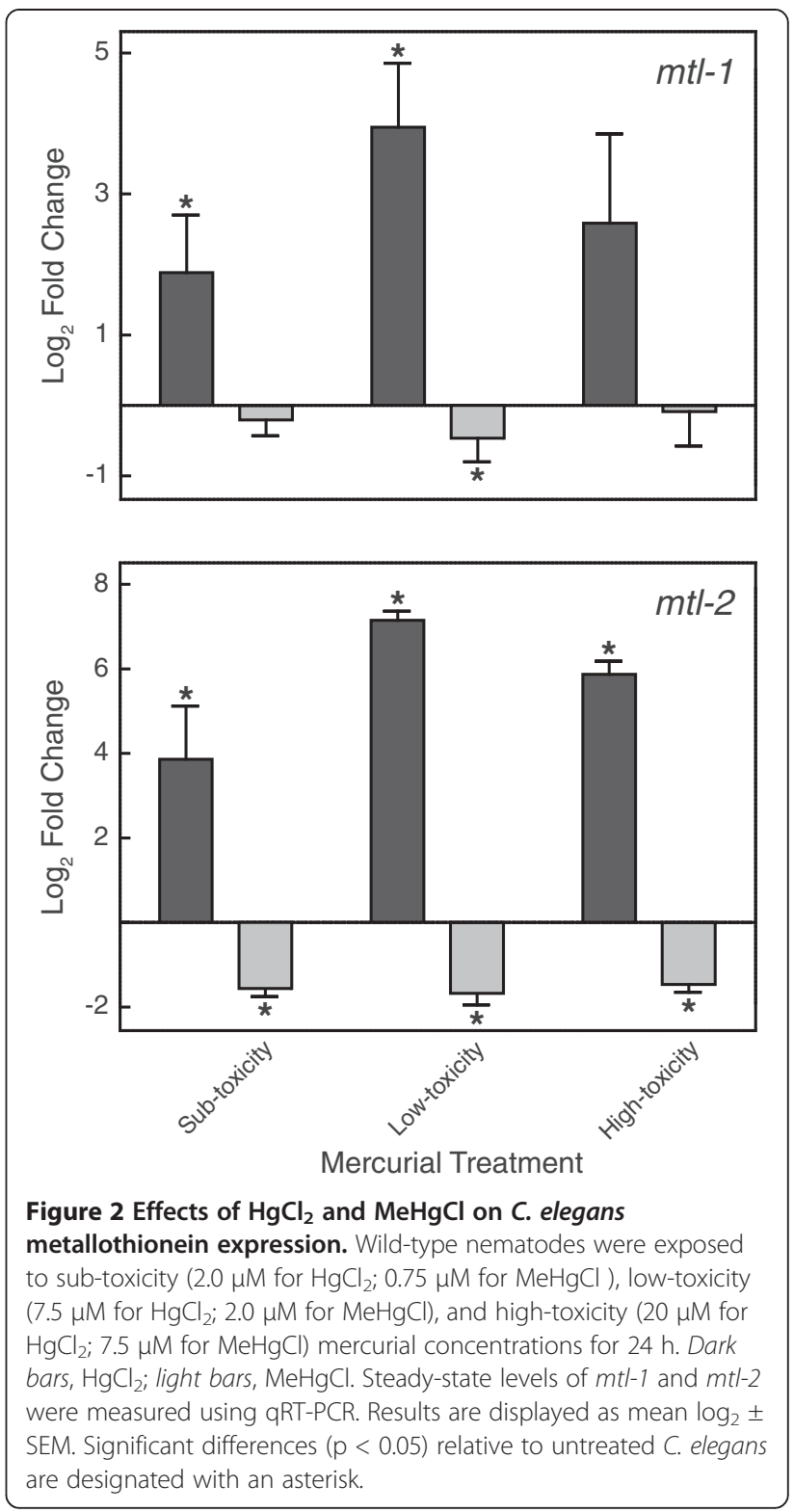

and mercurial treatment conditions, 12 unique expression patterns were generated (Figure 5). The number of genes assigned to each pattern varied from 23 genes (pattern 5) to 683 (pattern 8). In each pattern, $\mathrm{HgCl}_{2}$ and $\mathrm{MeHgCl}$ exposure had different effects on gene expression, which further demonstrated the extent to which $\mathrm{HgCl}_{2}$ and $\mathrm{MeHgCl}$ had different effects on transcription. A list of the genes in the different EPIG patterns can be found in Additional file 3: Table S5.

Bioinformatics analyses of genes in different EPIG patterns elucidated the biological processes affected by $\mathrm{HgCl}_{2}$ and $\mathrm{MeHgCl}$ exposure. The efficacy of EPIG in grouping genes with related biological processes was evinced by the greater number of significantly enriched GO categories relative to analysis of the total DEGs. Among the 12 EPIG 

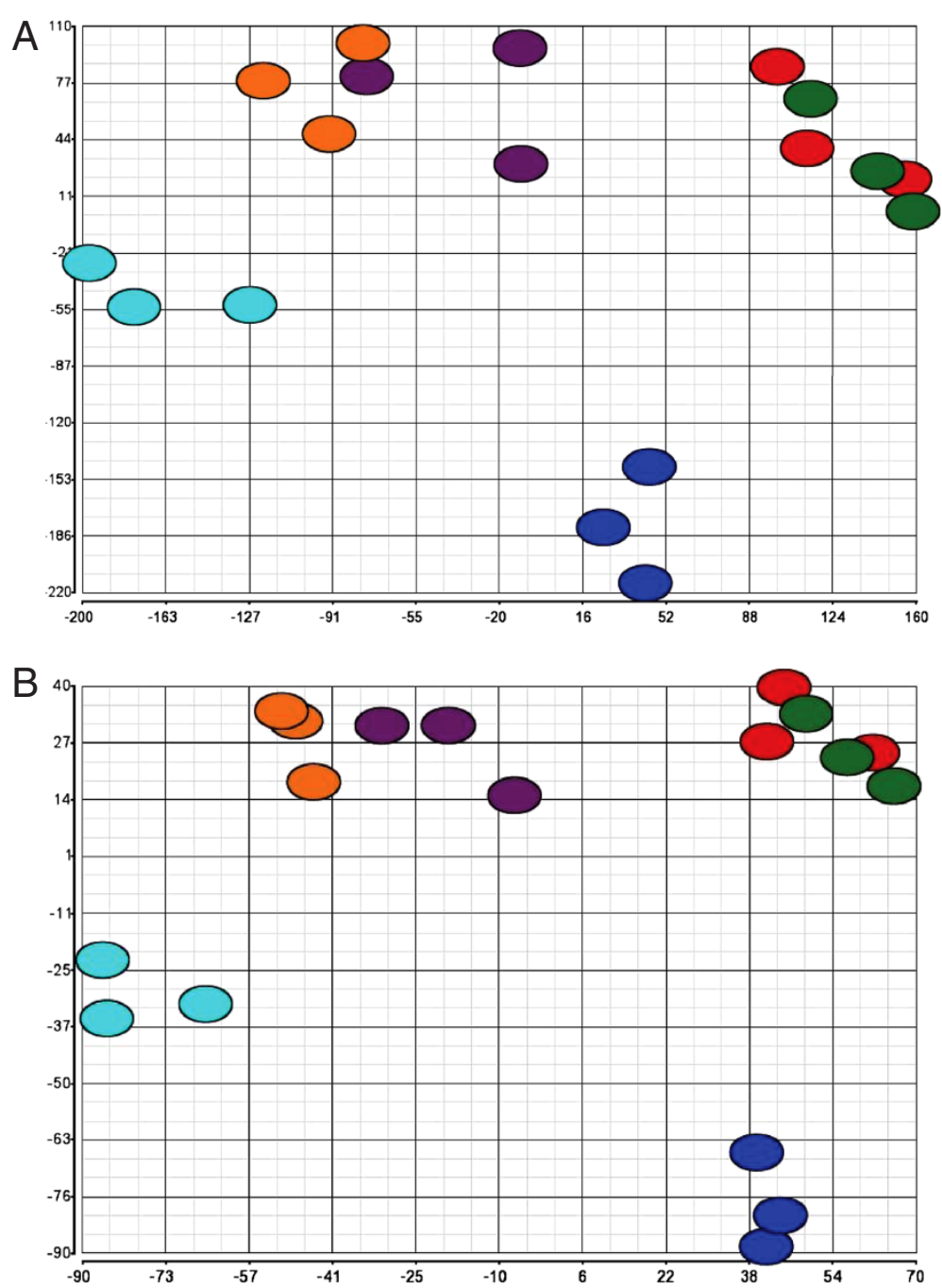

Figure 3 Principal components analysis. Panel A, PCA using all of the genes on the microarray; Panel B, PCA using only significantly, differentially expressed genes. Analyses were performed on three pairs of independent biological replicates. Treatments are designated: $2.0 \mu \mathrm{M}$ (red), $7.5 \mu \mathrm{M}$ (green) and $20 \mu \mathrm{M}$ (dark blue) for $\mathrm{HgCl}_{2}$ and $0.75 \mu \mathrm{M}$ (purple), $2.0 \mu \mathrm{M}$ (orange) and $7.5 \mu \mathrm{M}$ (light blue) for MeHgCl.

patterns, there were 104 significantly enriched GO categories. By comparison, analysis of DEGs by treatment and differential expression yielded 38 significantly enriched GO categories. Examining the pattern-specific GO categories defined how C. elegans responded to mercurials, and how these responses differed. The five most significantly enriched GO biological processes for each EPIG pattern are listed in Table 5. All significantly enriched biological process and molecular function GO categories are listed in Additional file 4: Table S6.

The GO category embryonic development associated with birth or egg hatching was significantly enriched in EPIG patterns 5, 7, 8, and 12. However, that ontology comprised 3,555 genes, which were involved in a variety of functions. Patterns 1 and 2 included genes that were upregulated in response to $\mathrm{HgCl}_{2}$, but were down-regulated or not affected by $\mathrm{MeHgCl}$. In both patterns, there was an enrichment of genes in the metal transport GO category, which included a number of potassium channels (ccb-2, egl-23, irk-2, kcnl-2, shl-1, slo-2, twk-29, twk-33, twk-35, twk-43, twk-46, unc-8, C53A5.5). Potassium channels have been reported to be inhibited by $\mathrm{HgCl}_{2}$ and unaffected by $\mathrm{MeHgCl}$ exposure [30,31]. It is possible that $\mathrm{HgCl}_{2}$, but not $\mathrm{MeHgCl}$, inhibited potassium channel activity in C. elegans, and that the nematode responded by increased transcription of the affected proteins. However, further investigation is required to determine if this is the case.

Pattern 8 comprised 683 genes that were down-regulated in response to $\mathrm{HgCl}_{2}$ and up-regulated in response to $\mathrm{MeHgCl}$. There was a significant enrichment of genes in the protein catabolic process, including components of the proteasome (pas-1, pas-2, pas-3, pas-4, pas-5, pas-6, pas-7, pbs-2, pbs-4, pbs-6, pbs-7rpt-1, rpt-2, rpt-3, rpt-5, $r p t-6)$, ubiquitin ligases (skr-2 and $s k r-18)$, and ubiquitin- 

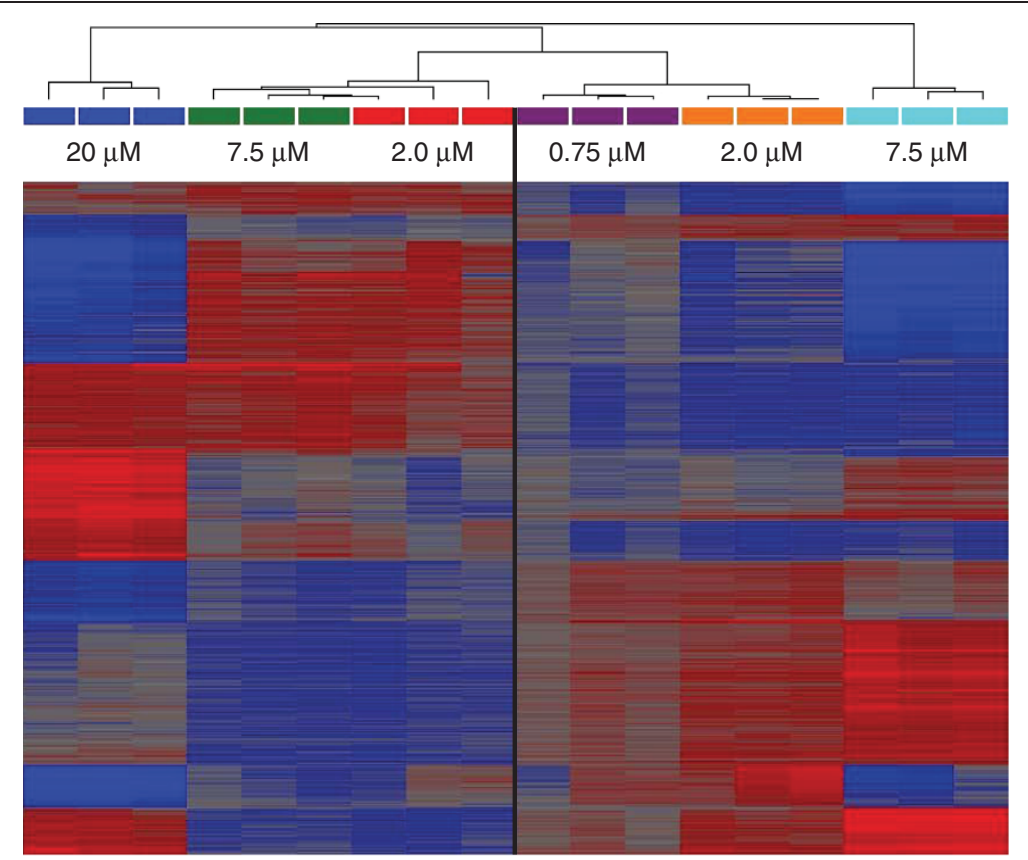

$\mathrm{HgCl}_{2}$

$\mathrm{MeHgCl}$

Figure 4 Hierarchical clustering of microarray experimental replicates. Hierarchical clustering was performed using three independent biological replicates for $\mathrm{C}$. elegans exposed to sub-, low- and high-toxicity $\mathrm{HgCl}_{2}$ and $\mathrm{MeHgCl}$ concentrations. Red indicates up-regulation of a gene and blue indicates down-regulation of a gene. The dendrogram indicates the degree to which the expression profiles of individual replicates are similar.

specific proteases (usp-14, usp-48, usp-5). This suggested that nematodes responded to an increase in the level of methylmercury-damaged proteins by up-regulating the ubiquitin-proteasome system.

Pattern 9 contained 232 genes whose levels of expression increased at high-toxicity $\mathrm{MeHgCl}$ exposures, but were largely unaffected by sub- and low-toxicity $\mathrm{MeHgCl}$ and all $\mathrm{HgCl}_{2}$ exposures. The most significantly enriched GO was $t R N A$ aminoacylation for protein translation, which included the tRNA synthetases for asparagine, aspartic acid, glycine, methionine, serine, tyrosine and valine. $\mathrm{MeHgCl}$ inhibits protein synthesis, which has been attributed to the ability of $\mathrm{MeHgCl}$ to disrupt aminoacyltRNA synthetase activity [32]. The data in this report suggested that nematodes increased transcription of aminoacyl-tRNA synthetases to compensate for the inhibition of these enzymes by $\mathrm{MeHgCl}$.

Functional analysis of mercury-responsive $C$. elegans genes Exposure to $\mathrm{HgCl}_{2}$ and $\mathrm{MeHgCl}$ resulted in the upregulation of hundreds of $C$. elegans genes. We hypothesized that up-regulated genes were likely to be important in protecting $C$. elegans against mercurial toxicity. To investigate this hypothesis, RNAi was used to assess the effects of knocking down gene expression on C. elegans growth in the presence of $\mathrm{HgCl}_{2}$ or $\mathrm{MeHgCl}$. Genes whose level of expression increased $>2$-fold under all $\mathrm{HgCl}_{2}$ exposure conditions and the sub- and low-toxicity $\mathrm{MeHgCl}$ exposures were selected. In addition, genes whose level of expression increased $>5$-fold at the high-toxicity $\mathrm{MeHgCl}$ exposure were selected. Using these selection criteria, 599 genes were tested, which included 258, 276, and 65 genes that were up-regulated by $\mathrm{HgCl}_{2}, \mathrm{MeHgCl}$, and both mercurials, respectively.

Gene-mercurial interactions were tested for both mercurials for all genes. An interaction was identified when gene knockdown and mercurial exposure resulted in growth that was significantly different from the predicted additive effects of the independent mercurial exposure and knockdown in gene expression.

In the initial screen, significant gene-mercurial interactions to at least one mercurial for 155 genes were observed. The effect on growth of knocking down these genes concomitant with mercurial exposure was then quantitatively assessed. For each gene-mercurial combination, interaction parameters and p-values were calculated. A positive interaction parameter indicated that nematodes exposed to mercurial and dsRNA had greater than predicted growth (i.e. knocking down the gene increased the nematodes' resistance to the mercurial). A negative interaction indicated that nematodes exposed to both mercurial and dsRNA had less than predicted growth 
Table 4 Enriched GO biological processes for differentially expressed genes

\begin{tabular}{|c|c|c|c|}
\hline Mercurial & Toxicity & Change in expression & Biological process (p-value) \\
\hline \multirow[t]{27}{*}{$\mathrm{MeHgCl}$} & Sub-toxic & up-regulated & Metabolic process $(0.00097)$ \\
\hline & \multirow{5}{*}{ Low-toxic } & \multirow{4}{*}{ up-regulated } & Lipid glycosylation (4.6E-05) \\
\hline & & & Response to heat $(0.00084)$ \\
\hline & & & Carbohydrate metabolic process $(0.0084)$ \\
\hline & & & Oxidation reduction (0.04) \\
\hline & & down-regulated & Regulation of transcription (0.032) \\
\hline & \multirow{21}{*}{ High-toxic } & \multirow{5}{*}{ up-regulated } & Post-translational protein modification (3.4E-67) \\
\hline & & & Vitelline membrane formation (8.5E-07) \\
\hline & & & Lipid glycosylation (1.1E-05) \\
\hline & & & Response to heat $(0.0022)$ \\
\hline & & & Enterobactin biosynthetic process $(0.044)$ \\
\hline & & \multirow{16}{*}{ down-regulated } & Cell adhesion (9.5E-06) \\
\hline & & & Body morphogenesis (1.8E-05) \\
\hline & & & Cell-matrix adhesion (4.7E-05) \\
\hline & & & Chitin catabolic process $(0.00021)$ \\
\hline & & & Regulation of transcription (0.0012) \\
\hline & & & Cell wall macromolecule catabolic process (0.025) \\
\hline & & & Defense response $(0.0035)$ \\
\hline & & & Tail morphogenesis (0.0044) \\
\hline & & & Proteolysis (0.0046) \\
\hline & & & Cilium morphogenesis (0.012) \\
\hline & & & Neuron recognition $(0.021)$ \\
\hline & & & Lipid transport (0.021) \\
\hline & & & Ubiquitin-dependent catabolic process (0.032) \\
\hline & & & Response to oxidative stress (0.035) \\
\hline & & & Protein-DNA complex assembly $(0.042)$ \\
\hline & & & Regulation of cell migration (0.046) \\
\hline \multirow[t]{10}{*}{$\mathrm{HgCl}_{2}$} & Low-toxic & up-regulated & Proteolysis (7.4E-06) \\
\hline & \multirow{9}{*}{ High-toxic } & \multirow{5}{*}{ up-regulated } & Lipid glycosylation (2.5E-14) \\
\hline & & & Transmembrane transport (1.1E-06) \\
\hline & & & Carbohydrate metabolic process (2.1E-06) \\
\hline & & & Extracellular matrix organization (1.3E-05) \\
\hline & & & Oxidation reduction (0.0084) \\
\hline & & \multirow{4}{*}{ down-regulated } & Body morphogenesis $(6.8 \mathrm{E}-10)$ \\
\hline & & & Locomotion (0.018) \\
\hline & & & Morphogenesis of an epithelium (0.024) \\
\hline & & & Regulation of multicellular organism growth (0.036) \\
\hline
\end{tabular}

(i.e. knocking down the gene decreased the nematodes' resistance to that mercurial).

Eighteen genes showed significant gene-mercurial interactions (Table 6). Genes that had positive genemercurial interactions included those encoding choline kinase $(c k b-2)$, an F-box A protein (fbxa-136), an ATPbinding cassette transporter (wht-3), and a C-type lectin (clec-163). Genes that had negative gene-mercurial interactions included genes encoding: $\gamma$-glutamylcysteine synthetase ( $g c s-1)$, a member of the tetraspanin integral membrane protein family (tsp-5), a poly-ADP-ribose metabolism enzyme ( $p m e-4)$, an F-box A protein ( $f b x a-$ 116), and a long-chain fatty acid elongation enzyme (elo-6). The remaining genes have limited information 


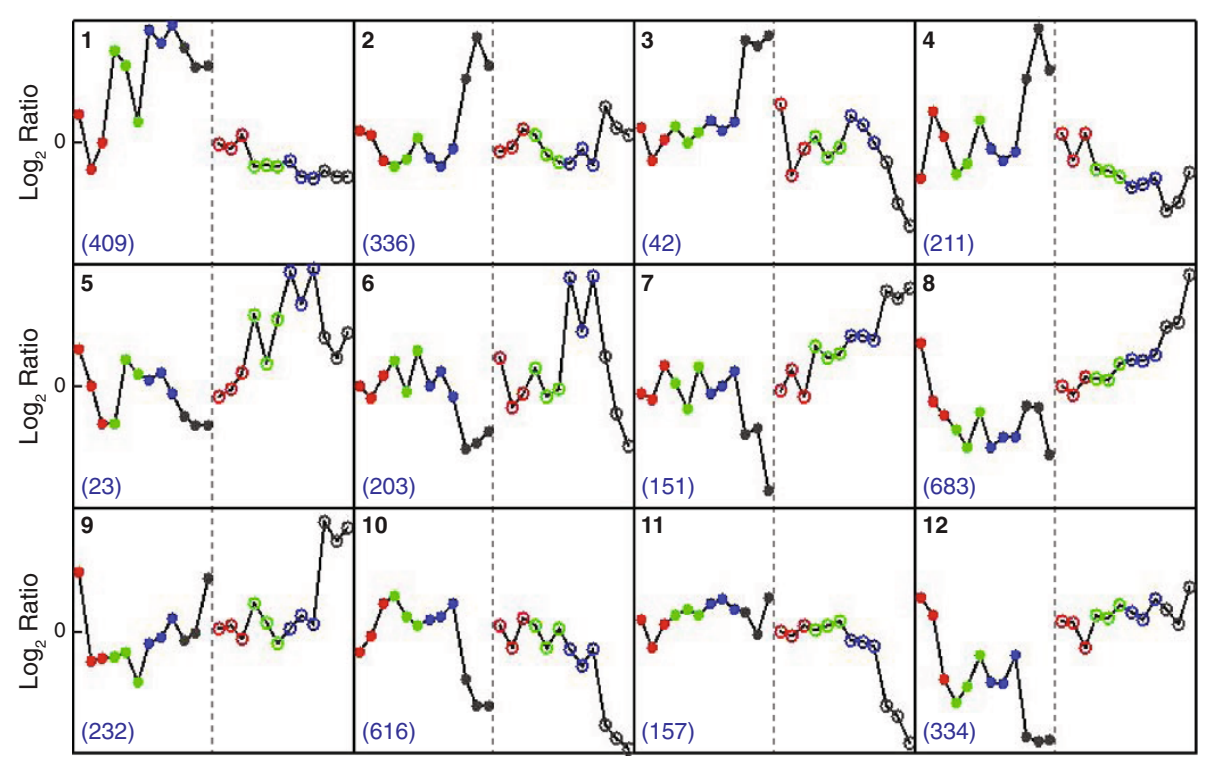

Figure 5 EPIG clustering of co-expressed genes. The average $\log _{2}$ fold-change of genes in the pattern for each experimental replicate and treatment is represented by the individual data points in each box. Red, green, blue, and black data points are untreated, sub-, low-, and hightoxicity exposures, respectively. Data points to the left of the dotted line (closed circles) are $\mathrm{HgCl}_{2}$-responsive genes and those to the right (open circles) are $\mathrm{MeHgCl}$-responsive. The value in the upper left indicates the identification number of the EPIG pattern. The value in the lower left hand indicates the number of genes in the specific pattern. The identity of the genes in each pattern can be found in Additional file 3: Table S5.

related to their function. Of the 20 significant interactions, two genes showed significant gene-mercurial interactions with both mercurials: gcs-1 and F14F9.4, which encodes a hypothetical protein. The remaining gene-mercurial interactions were mercurial-specific. The results of all C. elegans gene-mercurial interactions are listed in Additional file 5: Table S7.

\section{Effect of mercurials on gene expression in human cells}

Results with $C$. elegans indicated that transcriptional responses varied by type of mercurial. To determine if a similar response occurred in human cells, the effects of $\mathrm{HgCl}_{2}$ and $\mathrm{MeHgCl}$ exposure on transcription in three human-derived cell lines: SK-N-SH, HepG2 and HEK293 were examined. The effects on the steady state mRNA levels of human homologs to C. elegans genes for which there were significant gene-mercurial interactions were determined: ABCG2 (C. elegans WHT-3), a transporter that exports chemotherapeutic agents from cells and is up-regulated in many cancers [33]; BACE1 (C. elegans ASP-7), the rate limiting enzyme for the production of $\beta$-amyloid peptide [34]; BACE2, a BACE1 homolog, though less is known about its function; choline kinases CHKA and CHKB (C. elegans CKB-2), generate phosphocholine [35]; ELOVL3 and ELOVL6 (C. elegans ELO-6), synthesize saturated and mono-unsaturated long-chain fatty acids [36]; GCLC (C. elegans GCS-1), glutamate-cysteine ligase catalytic subunit for the rate limiting enzyme in glutathione synthesis [37]; and PARG
(C. elegans PME-4), catalyzes the hydrolysis of poly(ADP-ribose) [38].

A total of 162 cell line-mercurial concentration-gene combinations were tested. Of these, 36 resulted in a significant affect on gene expression, and every gene was differentially expressed in at least one condition (Table 7). Interestingly, while the C. elegans homologs of these genes were all up-regulated in response to at least one mercurial, many of the human homologs were down-regulated. This was evident in the HepG2 cells, where PARG, ELOVL6, BACE1, CHKA, CHKB, and $\mathrm{ABCG} 2$ were down-regulated in response to $\mathrm{MeHgCl}$ exposure. There were also cell line specific responses to mercurial exposure. For example, BACE2 was up-regulated at the $\mathrm{HgCl}_{2} \mathrm{EC}_{20}$ and $\mathrm{EC}_{50}$ in SK-N-SH cells, but was down-regulated at the $\mathrm{EC}_{50}$ in HEK293 cells.

As was observed in C. elegans, $\mathrm{HgCl}_{2}$ and $\mathrm{MeHgCl}$ had different effects on transcription. For example, in HepG2 cells, both $\mathrm{EC}_{20}$ and $\mathrm{EC}_{50} \mathrm{MeHgCl}$ treatments resulted in an $\sim 10$-fold increase in ELOVL3 levels, while $\mathrm{HgCl}_{2}$ exposure had no effect on ELOVL3 mRNA levels. Of the 36 conditions that resulted in a significant change in gene expression, 24 were unique to a specific cell linemercurial combination. There were six conditions where both mercurials, at equitoxic concentrations, induced similar changes in gene expression. In SK-N-SH cells, CHKB was up-regulated by $\mathrm{EC}_{50}$ exposures to both mercurials, and in HEK293 cells, ELOVL3 was up-regulated by $\mathrm{EC}_{50}$ exposures to both mercurials. In HepG2 cells, GCLC was 
Table 5 Significantly affected GO biological process in each EPIG pattern

\begin{tabular}{|c|c|}
\hline $\begin{array}{l}\text { EPIG } \\
\text { pattern }\end{array}$ & Biological process ( $p$ value) \\
\hline \multirow{5}{*}{1} & Oxidative phosphorylation (0.00013) \\
\hline & Ion transport (0.00020) \\
\hline & Response to drug (0.00024) \\
\hline & Monovalent inorganic cation transport $(0.00031)$ \\
\hline & Metal ion transport (0.00032) \\
\hline \multirow{4}{*}{2} & Lipid glycosylation (0.0011) \\
\hline & Monovalent inorganic cation transport $(0.0043)$ \\
\hline & Metal ion transport $(0.0045)$ \\
\hline & Transport (0.026) \\
\hline 3 & Lipid storage (0.033) \\
\hline \multirow{5}{*}{4} & Defecation (3.4E-05) \\
\hline & Oxygen transport $(0.00029)$ \\
\hline & Regulation of pharyngeal pumping (0.00037) \\
\hline & Transmembrane transport $(0.0084)$ \\
\hline & Neurotransmitter transport (0.021) \\
\hline \multirow[b]{2}{*}{5} & Cytokinesis (1.5E-06) \\
\hline & $\begin{array}{l}\text { Embryonic development ending in birth or egg hatching } \\
\qquad(0.045)\end{array}$ \\
\hline 6 & Meiosis (0.018) \\
\hline \multirow{5}{*}{7} & $\begin{array}{l}\text { Embryonic development ending in birth or egg hatching } \\
\qquad(6.1 \mathrm{E}-08)\end{array}$ \\
\hline & Mitotic spindle organization (1.2E-05) \\
\hline & Reproduction (1.8E-05) \\
\hline & Cytokinesis (0.00027) \\
\hline & Germ cell development (0.0051) \\
\hline
\end{tabular}

Embryonic development ending in birth or egg hatching (1.4E-28)

8

Nematode larval development (7.1E-14)

Genitalia development (1.0E-12)

Receptor-mediated endocytosis (2.7E-11)

Protein catabolic process (1.3E-8)

tRNA aminoacylation for protein translation (1.1E-06)

9

Lipid glycosylation (0.0020)

Positive regulation of growth rate (0.033)

Lipid metabolic process $(0.00073)$

Positive regulation of programmed cell death (0.0019)

10

Lipid transport (0.0028)

Body morphogenesis (0.0047)

Cell adhesion (0.0078)

Oviposition (0.014)

11

Transmembrane transport (0.020)
Table 5 Significantly affected GO biological process in each EPIG pattern (Continued)

Embryonic development ending in birth or egg hatching (4.2E-16)

Cell division (9.2E-10)

12

Morphogenesis of an epithelium (1.3E-6)

Mitotic spindle organization (4.1E-6)

Embryonic pattern specification (2.3E-5)

up-regulated by NOAEL and $\mathrm{EC}_{20} \mathrm{HgCl}_{2}$ and $\mathrm{MeHgCl}$ treatments, while ELOVL6 and CHKA were down-regulated by $\mathrm{EC}_{20}$ and NOAEL treatments, respectively. There were no instances in which a gene was significantly up-regulated by one mercurial and significantly downregulated by the other. Overall, these results were similar to that observed in C. elegans, where $\mathrm{HgCl}_{2}$ and $\mathrm{MeHgCl}$ exposure showed metal-specific effects on gene expression.

\section{Functional analysis of gene-mercurial interactions of human homologs}

A subset of C. elegans genes up-regulated in response to mercurial exposure was found to be important in the nematode response to mercurial exposure. To determine if the human homologs of these genes also affected the mammalian response to mercurial exposure, the effect of gene knockdown on the viability of SK-N-SH, HepG2 and HEK293 cells after a $24 \mathrm{~h}$ exposure to estimated $\mathrm{EC}_{50}$ mercurial concentrations was determined. There was no detectable ABCG2 expression in SK-N-SH cells, and BACE2 was not significantly knocked down in SK-N-SH and HepG2 cells, therefore these conditions were not tested. In all other cases, siRNA treatment resulted in a significant decrease in target mRNA (Additional file 1: Figure S4).

As with the C. elegans RNAi experiment, genes were deemed critical to the cells' response to mercurial exposure if there was a significant gene-mercurial interaction. A positive interaction indicated more than expected viable cells, and a negative interaction indicated fewer than expected viable cells. There were 11 significant interactions (Table 8). There were no significant interactions with either mercurial for BACE1, BACE2, or CHKB in any cell line. There were no instances in which a gene-cell line combination resulted in a significant interaction with both $\mathrm{HgCl}_{2}$ and $\mathrm{MeHgCl}$. Ten of the significant interactions were negative, with only knockdown of ELOVL6 in $\mathrm{HgCl}_{2}$-treated $\mathrm{HepG} 2$ cells resulting in a positive interaction. This interaction resulted in a $58 \%$ increase in viable cells, which was the largest magnitude change of any gene-mercurial interaction. Knockdown of ELOVL3 resulted in negative interactions in $\mathrm{HgCl}_{2}$-treated SK-NSH cells and MeHgCl-treated HEK293 cells, and had no 
Table 6 C. elegans gene-mercurial interactions

\begin{tabular}{|c|c|c|c|c|}
\hline Mercurial & Sequence name & Gene name & Interaction p-value & Interaction parameter \\
\hline \multirow{10}{*}{$\mathrm{HgCl}_{2}$} & F14F9.4 & & 0.00072 & 161 \\
\hline & F59D6.2 & & 0.00036 & 129 \\
\hline & B0285.9 & $c k b-2$ & $1.20 \mathrm{E}-06$ & 122 \\
\hline & C54D10.8 & & 0.0022 & 122 \\
\hline & C18D4.2 & fbxa-136 & 0.0036 & 107 \\
\hline & F19C7.5 & & $3.00 \mathrm{E}-06$ & 95 \\
\hline & $\mathrm{C} 16 \mathrm{C} 10.12$ & wht-3 & 0.00022 & 94 \\
\hline & Y39A1B.1 & clec-163 & 0.0017 & 78 \\
\hline & T09F5.10 & & 0.0061 & 65 \\
\hline & F37B12.2 & gcs-1 & $2.40 \mathrm{E}-05$ & -228 \\
\hline \multirow{10}{*}{$\mathrm{MeHgCl}$} & F14F9.4 & & 0.0068 & 121 \\
\hline & K01D12.1 & & 0.0024 & 54 \\
\hline & F37B12.2 & gcs-1 & $2.9 \mathrm{E}-11$ & -354 \\
\hline & Y45F10B.1 & tsp-5 & 0.0016 & -153 \\
\hline & $\mathrm{H} 23 \mathrm{~L} 24.5$ & pme-4 & 0.0069 & -148 \\
\hline & Y113G7B.1 & $f b x a-116$ & 0.00057 & -137 \\
\hline & Y69E1A.8 & & 0.0021 & -104 \\
\hline & T05E7.4 & & 0.00013 & -103 \\
\hline & T22D1.2 & & 0.00079 & -101 \\
\hline & $\mathrm{F} 41 \mathrm{H} 10.8$ & elo-6 & 0.010 & -99 \\
\hline
\end{tabular}

effect in mercurial-treated HepG2 cells. Knockdown of $\mathrm{CHKA}$ in $\mathrm{MeHgCl}$-exposed cells resulted in a negative interaction in all three cell lines. However, significant $\mathrm{CHKA}-\mathrm{HgCl}_{2}$ interactions were not observed. Knockdown of $\mathrm{ABCG} 2$ in $\mathrm{MeHgCl}$-exposed cells resulted in negative interactions in HepG2 and HEK293 cells. All other gene-mercurial interactions were cell line-specific. There was a significant GCLC-mercurial effect only in SK-N-SH cells treated with $\mathrm{HgCl}_{2}$ and HepG2 cells treated with $\mathrm{MeHgCl}$. As the GCLC homolog, gcs-1, was the most critical resistance gene to both mercurials in C. elegans, it was expected that similar results would be observed in cell culture. As was observed in C. elegans, different genes are critical in the cellular response to different mercurials.

\section{Discussion}

In the present study, global transcriptome profiles for $C$. elegans exposed to sub-, low- and high-toxicity concentrations of $\mathrm{HgCl}_{2}$ and $\mathrm{MeHgCl}$ were compared. The use of three equitoxic levels of mercurial allowed for a more relevant comparison of the effects. After demonstrating the differences in C. elegans responses to $\mathrm{HgCl}_{2}$ and $\mathrm{MeHgCl}$ exposure, the role of selected genes in mercurial response was assessed in three human cell lines. In both C. elegans and mammalian cells, $\mathrm{HgCl}_{2}$ and $\mathrm{MeHgCl}$ exposure had unique effects on gene expression, and different genes were important in protecting the organism from mercurial toxicity.

At each equitoxic exposure, there were a greater number of DEGs in $\mathrm{MeHgCl}$-treated C. elegans than in $\mathrm{HgCl}_{2}$ treated. Furthermore, at each level of toxicity, there was a higher percentage of DEGs down-regulated by $\mathrm{MeHgCl}$, compared to $\mathrm{HgCl}_{2}$ : sub-toxicity $\left(0 \% \mathrm{HgCl}_{2}, 20 \% \mathrm{MeHgCl}\right.$ ), low-toxicity $\left(8 \% \mathrm{HgCl}_{2}, 41 \% \mathrm{MeHgCl}\right)$, high-toxicity (22\% $\left.\mathrm{HgCl}_{2}, 43 \% \mathrm{MeHgCl}\right)$. High percentages (41\%-76\%) of DEGs were down-regulated in response to $\mathrm{MeHgCl}$ in studies using mouse embryo fibroblasts [39]. In contrast, microarray analysis of livers from $\mathrm{HgCl}_{2}$-exposed zebrafish found approximately equal numbers of up- and downregulated genes, and analysis of $\mathrm{Hg}^{0}$-exposed rat lungs found more up-regulated than down-regulated genes $[22,40]$.

One of the most striking results of the present study was the degree to which the transcriptomes of $\mathrm{HgCl}_{2}$ and $\mathrm{MeHgCl}$ differed. There were very few common DEGs between mercurial exposures. PCA indicated that more variability was attributed to the mercurial species than the level of toxicity (Figure 3). Similarly, hierarchical clustering of DEGs at sub-and low-toxicity concentrations showed almost opposite transcriptional responses for $\mathrm{HgCl}_{2}$ and $\mathrm{MeHgCl}$ (Figure 4). At high-toxicity exposures, when cellular stress is elevated, one would expect similarities in the DEGs. There were 94 up-regulated and 14 down- 
Table 7 Effects of mercurial on gene expression in cells

\begin{tabular}{|c|c|c|c|c|c|c|c|c|c|c|c|c|c|c|c|c|c|c|c|}
\hline \multicolumn{2}{|c|}{ Genes } & \multicolumn{6}{|c|}{ SK-N-SH } & \multicolumn{6}{|c|}{ HepG2 } & \multicolumn{6}{|c|}{ HEK293 } \\
\hline \multirow[t]{2}{*}{ C. elegans } & \multirow[t]{2}{*}{ Human } & \multicolumn{3}{|c|}{$\mathrm{HgCl}_{2}$} & \multicolumn{3}{|c|}{$\mathrm{MeHgCl}$} & \multicolumn{3}{|c|}{$\mathrm{HgCl}_{2}$} & \multicolumn{3}{|c|}{$\mathrm{MeHgCl}$} & \multicolumn{3}{|c|}{$\mathrm{HgCl}_{2}$} & \multicolumn{3}{|c|}{$\mathrm{MeHgCl}$} \\
\hline & & NOAEL & $\mathrm{EC}_{20}$ & $\overline{E C_{50}}$ & NOAEL & $\mathrm{EC}_{20}$ & $\overline{\mathrm{EC}_{50}}$ & NOAEL & $\mathrm{EC}_{20}$ & $\overline{\mathrm{EC}_{50}}$ & NOAEL & $\mathrm{EC}_{20}$ & $\mathrm{EC}_{50}$ & NOAEL & $\mathrm{EC}_{20}$ & $\mathrm{EC}_{50}$ & NOAEL & $\mathrm{EC}_{20}$ & $\mathrm{EC}_{50}$ \\
\hline wht-3 & ABCG2 & \multicolumn{6}{|c|}{ Not Detected } & - & - & - & -2.0 & -3.0 & -5.3 & - & - & 1.9 & - & - & - \\
\hline \multirow{2}{*}{ asp-7 } & BACE1 & - & - & - & - & - & - & - & - & - & - & -1.9 & -3.1 & - & - & - & - & - & - \\
\hline & BACE2 & - & 1.8 & 2.8 & - & - & - & - & - & - & - & - & - & - & - & -1.7 & - & - & - \\
\hline \multirow{2}{*}{$c k b-2$} & CHKA & - & - & 3.8 & - & - & - & - & - & -1.5 & - & -1.4 & -2.3 & - & - & 1.9 & - & - & - \\
\hline & CHKB & - & - & 2.0 & 1.8 & 2.7 & 2.0 & - & - & - & -1.2 & - & -2.0 & - & - & - & - & - & - \\
\hline \multirow{2}{*}{ elo-6 } & ELOVL3 & - & - & 9.8 & - & - & - & - & - & - & - & 11 & 10 & - & - & 8.3 & - & - & 7.0 \\
\hline & ELOVL6 & - & - & 1.8 & - & - & - & - & -2.0 & - & -2.2 & -2.4 & -2.8 & - & - & - & - & - & - \\
\hline gcs-1 & GCLC & - & - & 2.6 & - & - & - & 2.5 & 2.6 & - & 2.8 & 2.1 & - & - & - & - & - & - & - \\
\hline pme-4 & PARG & - & - & - & - & - & - & - & - & - & - & - & -2.4 & - & - & - & - & - & - \\
\hline
\end{tabular}

The number in each cell indicates the fold-change in expression. Cells containing "-_ indicate no significant change in gene expression. 
Table 8 Gene-mercurial interactions in human cells

\begin{tabular}{|c|c|c|c|c|}
\hline \multirow{2}{*}{ Gene } & \multirow{2}{*}{ Mercurial } & \multicolumn{3}{|c|}{ Interaction parameters ( $p$-values) } \\
\hline & & SK-N-SH & HepG2 & HEK293 \\
\hline \multirow{2}{*}{ ABCG2 } & $\mathrm{HgCl}_{2}$ & NA & $-1 \%(0.83)$ & $-5 \%(0.56)$ \\
\hline & $\mathrm{MeHgCl}$ & NA & $-8 \%(0.038)$ & $-28 \%(0.0068)$ \\
\hline \multirow{2}{*}{ BACE1 } & $\mathrm{HgCl}_{2}$ & $-21 \%(0.057)$ & $21 \%(0.069)$ & $-1 \%(0.92)$ \\
\hline & $\mathrm{MeHgCl}$ & $-11 \%(0.22)$ & $-3 \%(0.68)$ & $-28 \%(0.063)$ \\
\hline \multirow{2}{*}{ BACE2 } & $\mathrm{HgCl}_{2}$ & NA & NA & $-2 \%(0.87)$ \\
\hline & $\mathrm{MeHgCl}$ & NA & NA & $-26 \%(0.30)$ \\
\hline \multirow{2}{*}{ CHKA } & $\mathrm{HgCl}_{2}$ & $-26 \%(0.088)$ & $-3 \%(0.72)$ & $-20 \%(0.11)$ \\
\hline & $\mathrm{MeHgCl}$ & $-27 \%(0.037)$ & $-21 \%(0.0028)$ & $-31 \%(0.021)$ \\
\hline \multirow{2}{*}{$\mathrm{CHKB}$} & $\mathrm{HgCl}_{2}$ & $-18 \%(0.39)$ & $19 \%(0.24)$ & $4 \%(0.71)$ \\
\hline & $\mathrm{MeHgCl}$ & $-10 \%(0.24)$ & $1 \%(0.92)$ & $5 \%(0.78)$ \\
\hline \multirow{2}{*}{ ELOVL3 } & $\mathrm{HgCl}_{2}$ & $-21 \%(0.0066)$ & $-4 \%(0.76)$ & $-7 \%(0.62)$ \\
\hline & $\mathrm{MeHgCl}$ & $-5 \%(0.53)$ & $5 \%(0.35)$ & $-37 \%(0.0023)$ \\
\hline \multirow{2}{*}{ ELOVL6 } & $\mathrm{HgCl}_{2}$ & $-25 \%(0.35)$ & $58 \%(<0.001)$ & $3 \%(0.91)$ \\
\hline & $\mathrm{MeHgCl}$ & $-28 \%(0.071)$ & $3 \%(0.57)$ & $20 \%(0.43)$ \\
\hline \multirow{2}{*}{ GCLC } & $\mathrm{HgCl}_{2}$ & $-15 \%(0.031)$ & $0 \%(1.00)$ & $-25 \%(0.060)$ \\
\hline & $\mathrm{MeHgCl}$ & $-2 \%(0.45)$ & $-22 \%(<0.001)$ & $3 \%(0.82)$ \\
\hline \multirow{2}{*}{ PARG } & $\mathrm{HgCl}_{2}$ & $-15 \%(0.15)$ & $-4 \%(0.59)$ & $-22 \%(0.20)$ \\
\hline & $\mathrm{MeHgCl}$ & $6 \%(0.61)$ & $1 \%(0.96)$ & $-53 \%(0.0076)$ \\
\hline
\end{tabular}

Significant (at the 0.05 alpha cutoff) positive and negative gene-mercurial interactions are highlighted in bold. Numbers in cells indicate the percent change in viable cells from predicted additive effect of gene knock-down and mercurial exposure. "NA" indicates a condition that was not tested.

regulated common DEGs following exposure to hightoxicity concentrations of $\mathrm{HgCl}_{2}$ and $\mathrm{MeHgCl}$. While the majority of these genes were poorly characterized, there were several known stress-response genes: seven UDP-glucuronosyl transferases, six glutathione $S$-transferases, and a heat shock protein. The common DEGs, however, represented less than $3.5 \%$ of the total number of DEGs. The differences in the $\mathrm{HgCl}_{2}$ and $\mathrm{MeHgCl}$ transcriptomes suggest that the two mercurials have different mechanisms of action.

$\mathrm{HgCl}_{2}$ and $\mathrm{MeHgCl}$ differed in the number of positive and negative gene-mercurial interactions. Of the 18 genes for which there was a gene-mercurial interaction, only two interacted with both $\mathrm{HgCl}_{2}$ and $\mathrm{MeHgCl}$. Of the ten significant gene- $\mathrm{MeHgCl}$ interactions, eight resulted in increased susceptibility to $\mathrm{MeHgCl}$. Conversely, of the ten significant gene- $\mathrm{HgCl}_{2}$ interactions, nine resulted in increased tolerance to $\mathrm{HgCl}_{2}$. The differences in direction of the gene-mercurial interactions between the two mercurials and the paucity of similar gene-mercurial interactions were further evidence that the two mercurials acted through unique mechanisms at the molecular level.

Metallothionein binding of inorganic metals is a common detoxification mechanism. Therefore, increased mRNA levels were expected following mercurial exposure. The C. elegans metallothionein genes, $m t l-1$ and $m t l-2$, were up-regulated in response to $\mathrm{HgCl}_{2}$ exposure. They were however, downregulated following $\mathrm{MeHgCl}$ exposure. Previous publications in a variety of species report inconsistent induction of metallothioneins in response to $\mathrm{MeHgCl}$ exposure [41-44]. The present study is the first to report a downregulation of metallothionein gene expression in response to $\mathrm{MeHgCl}$ exposure. Although earlier studies showed that metallothioneins were incapable of binding methylmercury [45], more recent work indicated that metallothioneins could bind methylmercury [46]. In addition to binding metals, metallothioneins are also important in regulating the redox status of cells and preventing intracellular oxidative damage. Metallothioneins increase resistance to $\mathrm{MeHgCl}$ toxicity, possibly by protecting cellular components from mercurial-induced oxidative stress [47]. These data suggest that the increased sensitivity of $C$. elegans to $\mathrm{MeHgCl}$ may be a consequence of its inability to induce metallothionein expression in response to this mercurial.

In $\mathrm{MeHgCl}$-exposed C. elegans, decreased metallothionein levels likely result in increased reliance on glutathione-mediated detoxification. In the low-toxicity $\mathrm{MeHgCl}$ treatment, 13 glutathione $S$-transferases were up-regulated. Conversely, no glutathione $S$-transferases were up-regulated in the low-toxicity $\mathrm{HgCl}_{2}$ exposure. In high-toxicity treatments, there were 19 glutathione $S$-transferases up-regulated in $\mathrm{MeHgCl}$-exposed nematodes and seven in $\mathrm{HgCl}_{2}$-exposed nematodes. In addition, knockdown of gcs-1 increased C. elegans susceptibility to both mercurials; however, the effect was greater in $\mathrm{MeHgCl}$-exposed nematodes (Table 6). The human homo$\log$ of $g c s-1$, GCLC, was also critical in resistance to both mercurials in mammalian cells. Knockdown of GCLC resulted in significant negative interactions with $\mathrm{HgCl}_{2}$ in SK-N-SH and $\mathrm{MeHgCl}$ in HepG2 cells. Glutathione is important in resistance to both $\mathrm{HgCl}_{2}$ and $\mathrm{MeHgCl}$, but $\mathrm{MeHgCl}$-exposed C. elegans appear to be particularly dependent on glutathione-mediated resistance. Gene expression and knockdown results with both $C$. elegans and human cells suggest that glutathione may be a component of an evolutionarily conserved defense against mercurial (organic and inorganic) toxicity.

Co-exposure of PARG siRNA and $\mathrm{MeHgCl}$ in HEK293 cells resulted in the second largest observed gene-mercurial interaction, indicating the critical role of PARG in resistance to $\mathrm{MeHgCl}$ toxicity. In contrast, there were no significant PARG- $\mathrm{HgCl}_{2}$ interactions in any cell line. PARP (poly-ADP-ribose polymerase) catalyzes the addition of ADP-ribose to proteins, while PARG cleaves poly-ADPribose to ADP-ribose monomers [48]. In cases of severe stress, PARP becomes highly activated, which leads to over-production of poly-ADP-ribose and cell death [49]. This suggests that exposure to $\mathrm{MeHgCl}$ increases PARP activity, and that PARG is necessary to maintain poly- 
ADP-ribose homeostasis. Treatment with the PARP inhibitor 3, 4-dihydro-5-[4-(1-piperidinyl)-butoxy]-1(2H)isoquinolinone decreased $\mathrm{MeHgCl}$-induced cell death in a dose-dependent manner [50]. PME-4, the C. elegans PARG homolog, was up-regulated 22-fold in low-toxicity and 35-fold in high-toxicity $\mathrm{MeHgCl}$ exposures. In addition, pme-4 knockdown during $\mathrm{MeHgCl}$ exposure resulted in the fourth greatest negative interaction, however, pme-4 knockdown during $\mathrm{HgCl}_{2}$ exposure did not produce a significant interaction. PME-4 is primarily expressed in the cytoplasm of neurons, and is predicted to be critical in preventing neurodegeneration [51]. Methylmercury is a neurotoxicant, thus PME-4 may be critical in maintaining neuron viability in $\mathrm{MeHgCl}$-exposed nematodes. These results suggest that disruption of poly-ADP-ribose homeostasis may be an evolutionarily conserved mechanism of $\mathrm{MeHgCl}$, but not $\mathrm{HgCl}_{2}$, toxicity.

ELO-6 was important in resistance to $\mathrm{MeHgCl}$, though it was down-regulated 2.5-fold in the high-toxicity $\mathrm{MeHgCl}$ exposure. ELO-6 is a long-chain fatty acid elongation enzyme that plays an essential role in growth of C. elegans [52]. There is evidence that suggests exposure to poly-unsaturated fatty acids mitigates $\mathrm{MeHgCl}$ toxicity in humans $[53,54]$.

EPIG pattern 8 was populated by genes down-regulated by $\mathrm{HgCl}_{2}$ and up-regulated by low- and high-toxicity $\mathrm{MeHgCl}$ exposures. There was a significant enrichment of genes involved in the ubiquitin-proteasome system in this group. In yeast, increased ubiquitination resulted in increased resistance to $\mathrm{MeHgCl}$ toxicity [55,56]. In addition, $\mathrm{MeHgCl}$-exposed mouse embryonic fibroblasts showed an enrichment of differentially expressed genes involved in the ubiquitin-proteasome system. These authors suggested that the removal of methylmercury-damaged proteins is critical for cell survival [23]. Recent work indicates that ubiquitination inhibits neuronal exit in cerebellar granule cell layers [57]. Patients suffering from Minamata disease exhibited hypoplasia of granule cell layer and degeneration of cerebellar granule cells, which may be due in part to $\mathrm{MeHgCl}$ inhibition of granule cell migration $[58,59]$. It is reasonable to hypothesize that increased ubiquitination, while protective against $\mathrm{MeHgCl}$ in some cell types, may contribute to the neuropathology of methylmercury exposure by inhibiting granule cell migration.

In the present study, considerable differences were observed on how exposure to different mercurials affects gene expression and the genes that mediate the organism's response to mercury. These differences were observed in both $C$. elegans and human cell lines, demonstrating the conserved nature of this phenomenon. While there are many instances in which a specific gene was differentially expressed in response to only one mercurial there were no instances in which a gene was up-regulated by one mercurial and down-regulated by the other. These results suggest that, despite similarities in the known responses of the two mercurials, the two mercurials function differently at the molecular level. These data indicate that contrary to previous models that hypothesize the conversion of organic mercury to the inorganic species, organic and inorganic mercurials act by independent or unique molecular mechanisms.

\section{Conclusion}

Mercury is an environmental human toxicant that exists in multiple chemical forms. Despite years of research, only a fragmented understanding of the molecular mechanisms of mercurial toxicity exists. Furthermore, it is not known whether different mercurial species act similarly or dissimilarly at the molecular level. We performed microarray analysis of $C$. elegans exposed to three equitoxic concentrations of mercuric chloride $\left(\mathrm{HgCl}_{2}\right)$ and methylmercury chloride $(\mathrm{MeHgCl})$. Bioinformatics analysis indicated that the transcriptional effects of the two mercurials were vastly different. Next, we examined the effects of knocking down the expression of up-regulated genes on C. elegans growth. Of the $\sim 600$ genes tested, only two significantly affected growth in response to both mercurials. We examined the evolutionarily conserved nature of the mercurial response in three human-derived cell lines. Similar to what was observed in C. elegans, there was very little overlap in the transcriptional responses between $\mathrm{HgCl}_{2}$ and $\mathrm{MeHgCl}$. There was also very little overlap between the mercurials in the genes involved in resistance and susceptibility. These data indicate that contrary to previous models that hypothesize the conversion of organic mercury to the inorganic species, which is the active form of the metal, organic and inorganic mercurials function by independent or unique molecular mechanisms.

\section{Methods}

\section{Maintenance of $C$. elegans}

Wild-type N2 Bristol and NL2099 (rrf-3(pk1426) II) strains were obtained from the C. elegans Genetic Center. C. elegans were maintained at $20^{\circ} \mathrm{C}$ on K-agar plates with Escherichia coli OP50 as food [60].

\section{C. elegans treatment and RNA isolation}

Forty L4 stage N2 nematodes were placed on K-agar plates and allowed to grow for $4 \mathrm{~d}$ at $20^{\circ} \mathrm{C}$. Nematodes were then transferred into liquid S-medium containing E. coli OP50, and incubated at $20^{\circ} \mathrm{C}$ with constant agitation for $4 \mathrm{~d}$ [61]. Fifty-milliliter aliquots of mixed-stage C. elegans were then used for untreated control samples, or treated with sub- (2.0 $\mu \mathrm{M} \mathrm{HgCl} 2,0.75 \mu \mathrm{M} \mathrm{MeHgCl})$, low- (7.5 $\mu \mathrm{M}$ $\left.\mathrm{HgCl}_{2}, 2.0 \mu \mathrm{M} \mathrm{MeHgCl}\right)$ or high- $(20 \mu \mathrm{M} \mathrm{HgCl}, 7.5 \mu \mathrm{M}$ $\mathrm{MeHgCl})$ toxicity mercurial concentrations for $24 \mathrm{~h}$. Nematodes were then collected by centrifugation and 
rinsed three times with $0.1 \mathrm{M} \mathrm{NaCl}$. Nematodes were isolated by sucrose floatation, frozen in liquid nitrogen, and then stored at $-80^{\circ} \mathrm{C}$ until used, as previously described [62].

To prepare total RNA, nematodes were ground to a fine powder in a liquid nitrogen-cooled mortar and pestle, and RNA was isolated using the RNeasy Midi Kit, according to manufacturer's instructions (Qiagen, Valencia, CA). Independently treated and control C. elegans cultures were used to generate three biological replicates for each treatment condition. The quality of the RNA was assessed using an Agilent 2100 Bioanalyzer (Palo Alto, CA).

\section{Microarray experiment and data analysis}

RNA was submitted to the NIEHS Microarray Group for labeling, probe hybridization and microarray scanning. Agilent C. elegans Gene Expression Microarrays, Ver. 1, which contain 21,000 probes encompassing all C. elegans open reading frames, were used in a single channel (1color) design. Data were obtained using Agilent Feature Extraction Software (Ver. 9.5) with the 1-color default parameters. This software performed error modeling, and adjusting for additive and multiplicative noise. Rosetta Resolver $^{\ominus}$ was used to identify differentially expressed genes using an error-weighted, 1-way ANOVA with a Bonferroni correction. A 2-fold change in expression, relative to untreated controls, and a p-value $<0.01$ was required for a gene to qualify as significantly, differentially expressed.

The EPIG pattern analysis tool was used to compare the transcription profiles of genes across different treatments [29]. In EPIG, the expression of a gene in each replicate was compared to the average expression of that gene in all untreated replicates. Genes with similar expression patterns were grouped together using the following parameters: correlation value (0.64), signal-to-noise ratio (3.0), and magnitude of change (0.5). Expression patterns were based on the six most highly correlated genes for each pattern.

Hierarchical clustering and principal components analysis (PCA) were performed using an agglomerative clustering method with Euclidean dissimilarity and a correlation dispersion matrix and normalized eigenvector scaling, respectively. Hierarchical clustering and PCA were performed using Partek Genomic Suites Ver. 6.5 software (Partek Incorporated, St. Louis, MO). Gene Ontology (GO) analysis was performed using Gene Ontology Enrichment Analysis Software Toolkit (GOEAST) [63]. The listed GO terms included four or more differentially expressed genes and pvalues $<0.05$. P-values were the result of Fisher's Exact Test.

\section{Assessing knockdown of C. elegans genes on growth during mercurial exposure}

The effects of gene knockdown on the sensitivity of C. elegans to mercurials were assessed using RNAi.
RNAi of selected genes was performed using the Open Biosystems (Huntsville, AL) or MRC Gene Service (University of Cambridge, UK) C. elegans RNAi bacterial feeding libraries $[64,65]$. These studies were performed using the RNAi hyper-sensitive $r r f-3$ strain to increase the responsiveness of the assay [66]. $\mathrm{EC}_{20} \mathrm{~s}$ of $r r f-3$ nematodes were $10.1 \mu \mathrm{M}$ for $\mathrm{HgCl}_{2}$ and $3.0 \mu \mathrm{M}$ for $\mathrm{MeHgCl}$, and were used in the RNAi studies (Additional file 1: Figure S1).

A two-generation approach was used to ensure gene knockdown throughout all C. elegans developmental stages. First, dsRNA-expressing bacterial cultures were grown overnight at $37^{\circ} \mathrm{C}$ with constant agitation. Isopropyl $\beta$-D-1thiogalactopyranoside was added to a final concentration of $2 \mathrm{mM}$, and the incubation continued for $1 \mathrm{~h}$. Bacteria were then collected and resuspended in complete K-medium [67]. Bacteria were added to appropriate wells in a 96-well plate, then nine $\mathrm{L} 4$ nematodes were added to each well, and incubated at $20^{\circ} \mathrm{C}$ for $48 \mathrm{~h}$. Following this incubation, 50 L1 larvae were transferred from each well to new 96-well plates, containing fresh dsRNA-expressing bacteria and $\mathrm{HgCl}_{2}$ or $\mathrm{MeHgCl}$. Nematodes were exposed to mercurial alone, gene-specific dsRNA alone, or mercurial and gene-specific dsRNA.

The effects of dsRNA and/or mercurial on C. elegans growth were assessed following a $48 \mathrm{~h}$ incubation. The initial assessment of gene-mercurial interactions was performed by visual observation. Any gene whose knockdown appeared to affect $C$. elegans growth, and thus a potential gene-mercurial interaction, was selected for additional analysis. All of the selected clones were sequenced to verify their identity. Of the 155 clones identified in the initial assessment, six were a different gene than described.

In the second phase of the screen, nematodes were fed dsRNA-expressing bacteria as described above. Growth was then measured using the C. elegans growth assay, as previously described [67]. A 2-way ANOVA was used to test for significant gene-mercury interactions using 500-800 nematodes per treatment condition. The criterion for a statistically significant interaction was $\mathrm{p}<0.01$.

\section{Maintenance of mammalian cell lines}

Human neuroblastoma (SK-N-SH; ATCC No. HTB-11), hepatocellular carcinoma (HepG2; ATCC No. HB8065) and embryonic kidney (HEK293; ATCC No. CRL-1573) cells were cultured in Minimum Essential Medium supplemented with $10 \%$ fetal bovine serum and $2 \mathrm{mM}$ L-glutamine. Cells were grown in a humidified incubator at $37^{\circ} \mathrm{C}$ under $5 \% \quad \mathrm{CO}_{2}$ atmosphere. These cell lines represent the primary target organs of mercurial toxicity: brain for $\mathrm{MeHgCl}$, kidney for $\mathrm{HgCl}_{2}$ and liver, which is a primary site for mercurial metabolism. 


\section{Mercurial cytotoxicity}

The toxicity of $\mathrm{HgCl}_{2}$ and $\mathrm{MeHgCl}$ to mammalian cells was determined using the Neutral Red cell viability assay, as previously described [68]. To determine the appropriate mercurial concentrations for gene expression and genemercurial interaction experiments, $24 \mathrm{~h}$ no observed adverse effect levels (NOAELs), 20\% effects concentrations $\left(\mathrm{EC}_{20} \mathrm{~s}\right)$ and $50 \%$ effects concentration $\left(\mathrm{EC}_{50} \mathrm{~s}\right)$ for cell viability were determined for untransfected cells and those transfected with non-homologous siRNA, respectively. $\mathrm{EC}_{20} \mathrm{~S}$ and $\mathrm{EC}_{50} \mathrm{~s}$ were estimated from the slopes of the dose response curves (Additional file 1: Figure S2). NOAELs were defined as the highest mercurial concentration that did not result in a significant decrease in cell viability.

\section{Effects of mercurials on gene expression}

Quantitative reverse transcription-real time-PCR (qRTPCR) was used to measure the effects of mercurials on the steady-state mRNA levels of the following human genes: ABCG2 (ATP-binding cassette, sub-family G (WHITE), member 2), BACE1 ( $\beta$-site APP cleaving enzyme 1$)$, BACE2 ( $\beta$-site APP cleaving enzyme 2$)$, CHKA (choline kinase $\alpha$ ), CHKB (choline kinase $\beta$ ), ELOVL3 (elongation of very long chain fatty acids-like 3), ELOVL6 (elongation of very long chain fatty acid-like 6), GCLC (glutamate-cysteine ligase, catalytic subunit), and PARG (poly-ADP-ribose glycohydrolase). To determine the effects of mercurials on gene expression in human cells, approximately $10^{5}$ cells were incubated in 6-well plates for $\sim 24 \mathrm{~h}$ after which mercurials at NOAEL, $\mathrm{EC}_{20}$, or $\mathrm{EC}_{50}$ concentrations were added (Additional file 6: Table S1). After $24 \mathrm{~h}$ incubation, total RNA was isolated, quantified, and stored at $-80^{\circ} \mathrm{C}$, as described above. cDNAs were prepared and qRT-PCR performed as previously described [69]. Fold changes in mRNA levels were calculated using the $\Delta \Delta C T$ method using $\beta$-actin as reference mRNA [70].

The effects of mercurial exposure on the expression of C. elegans metallothionein genes, $m t l-1$ and $m t l-2$, were also determined. qRT-PCR of $m t l-1$ and $m t l-2$ was performed using RNA isolated for the microarray experiments. Myosin light chain-2 mRNA $(m l c-2)$ was used as reference. Results are presented as mean \pm standard error ( $\mathrm{n}=3$ or 4 ). Data were analyzed using a 1-way ANOVA with a Dunnett's post-hoc test, with the criterion for statistical significance set at $\mathrm{p}<0.05$. Primers were designed using the open source Primer3 program and were purchased from Integrated DNA Technologies (Coralville, IA) (Additional file 6: Table S2) [71].

\section{Assessing the effect of gene knockdown on cell viability} during mercurial exposure

Approximately $10^{4}$ cells in 48-well plates were transfected in medium containing Opti-MEM (20\% final concentration), lipofectamine RNAiMAX (0.2\% final concentration, Invitrogen) and $25 \mathrm{nM}$ of the appropriate siRNA or non-homologous siRNA (Additional file 6: Table S3). Following transfection and recovery $(\sim 24 \mathrm{~h})$, mercurials were added to the medium. The concentrations used for SK-N-SH cells were $21 \mu \mathrm{M}$ for $\mathrm{HgCl}_{2}$ and $5 \mu \mathrm{M}$ for $\mathrm{MeHgCl}$; for HepG2 cells, $48 \mu \mathrm{M}$ for $\mathrm{HgCl}_{2}$ and $30 \mu \mathrm{M}$ for $\mathrm{MeHgCl}$; and for $\mathrm{HEK} 293$ cells, $17 \mu \mathrm{M}$ for $\mathrm{HgCl}_{2}$ and $6.8 \mu \mathrm{M}$ for $\mathrm{MeHgCl}$. Following $24 \mathrm{~h}$ incubation, cell viability was determined as described above. There were 3 to 5 experimental replicates for each condition.

Significance of gene-mercurial interactions was tested using a 3-way, mixed-effects ANOVA followed by a Bonferroni post-hoc test. In the ANOVA, siRNA and mercurial exposure were treated as fixed effects, and experimental day was treated as a random effect. The predicted cell survival of siRNA and mercurial coexposure with no interaction effect was computed from an ANOVA model. The interaction parameter for each gene-mercurial condition was determined by subtracting the predicted cell survival from the experimental cell survival of the siRNA-mercurial co-exposure. This value was divided by the predicted cell survival and reported as percent change from the "no interaction" value.

\section{Additional files}

Additional file 1: Figure S1. Effect of mercurials on rrf-3 C. elegans growth. Nematode size is expressed as the log of the absorbance (Extinction; EXT) of individual nematodes at the end of a $48 \mathrm{~h}$ exposure to $\mathrm{HgCl}_{2}$ (closed circles) or $\mathrm{MeHgCl}$ (closed squares) minus the mean absorbance of all nematodes at the beginning of exposure. Figure S2. Dose response curves for human cell lines. Human neuroblastoma (SK-N-SH), hepatocellular carcinoma (HepG2), and embryonic kidney (HEK293) cells were exposed to the indicated concentrations of $\mathrm{HgCl}_{2}$ (closed circles) or $\mathrm{MeHgCl}$ (closed squares) for $24 \mathrm{~h}$. Cell viability was determined by Neutral Red assay. Figure S3. Effect of mercurial exposure on C. elegans population distribution. The length (TOF) of nematodes was measured to determine size. Normed counts at each size represent the fraction of the total population. The red line indicates the population distribution of mercurial-treated nematodes and the black line indicates the population distribution of untreated nematodes. C. elegans population distributions were determined using a COPAS Biosort as previously described as previously described. Figure S4. Effectiveness of siRNA in cells. SK-N-SH (open bar), HepG2 (gray bar) and HEK293 (black bar) cells were transfected with gene-specific siRNA or non-homologous siRNA and incubated for $24 \mathrm{~h}$. Relative mRNA levels were measured using qRT-PCR. mRNA levels in cells treated with gene-specific siRNA were compared to mRNA levels in control cells to determine percent of control. Results display the mean percent of control \pm SEM.

Additional file 2: Table S4. All Differentially Expressed Genes following mercurial exposures.

Additional file 3: Table S5. A list of the genes contained in the different EPIG patterns.

Additional file 4: Table S6. All significantly enriched biological process and molecular function GO categories in each of the EPIG patterns.

Additional file 5: Table S7. All C. elegans gene-mercurial interactions. Additional file 6: Table S1. NOAEL, EC20 and EC50 for Mercurials in Human Cells. Table S2. Nucleotide sequences of primers used for qRTPCR. Table S3. Sequences of siRNA used in mammalian cell culture. 


\section{Competing interests}

The authors declare that there are no financial competing interests.

\section{Authors' contributions}

MKM carried out the mercurial toxicity, microarray, RNAi data analysis studies and drafted the manuscript. LAH performed the PCA analysis. JWC performed the EPIG analysis. MVS assisted with the statistical analysis of the C. elegans mercurial toxicity data. JHF conceived and designed the experiments, and prepared the final version of the manuscript. All authors read and approved the final manuscript.

\section{Acknowledgements}

The authors would like to acknowledge the support of Julie Rice and Paul Dunlap for technical assistance, Dr. Pierre Bushel for helpful discussions of data and bioinformatics analyses, and Dr. Changwon Lim for statistical determination of equimolar concentrations of the mercurials. All nematode strains used in this work were provided by the Caenorhabditis Genetics Center, which is funded by the National Center for Research Resources. Microarray data has been submitted to the NCBI Gene Expression Omnibus, and is accessible through GEO accession number GSE28915. This work was supported in part by the Intramural Research Program of the National Institute of Environmental Health Sciences, National Institutes of Health (Z01ES102045).

\section{Author details}

${ }^{1}$ Laboratory of Toxicology and Pharmacology, National Institute of Environmental Health Sciences, NIH, 111 T.W Alexander Drive, Research Triangle Park, P.O. Box 12233, 27709 Durham, NC, USA. ²SR International, Inc., Durham, NC, USA. ${ }^{3}$ Microarray and Genome Informatics Group, National Institute of Environmental Health Sciences, NIH, Research Triangle Park, Durham, NC, USA. ${ }^{4}$ Current address: Department of Biostatistical Sciences, Wake Forest University School of Medicine, Medical Center Boulevard, 27157 Winston-Salem, NC, USA.

Received: 1 March 2013 Accepted: 13 September 2013

Published: 11 October 2013

\section{References}

1. Malm O: Gold mining as a source of mercury exposure in the Brazilian Amazon. Environ Res 1998, 77(2):73-78.

2. National Toxicology Program: Toxicology and carcinogenesis studies of mercuric chloride in F344 rats and B6C3F1 mice. In Technical Report Series. Edited by National Toxicology Program. Research Triangle Park, NC: National Toxicology Program; 1993.

3. Clarkson TW, Magos L, Myers GJ: The toxicology of mercury - Current exposures and clinical manifestations. N Engl J Med 2003, 349(18):1731-1737.

4. Zachi EC, Ventura DF, Faria MAM, Taub A: Neuropsychological dysfunction related to earlier occupational exposure to mercury vapor. Braz J Med Biol Res 2007, 40(3):425-433.

5. Hodgson S, Nieuwenhuijsen MJ, Elliott P, Jarup L: Kidney disease mortality and environmental exposure to mercury. Am J Epidemiol 2007, 165(1):72-77.

6. Diez S: Human health effects of methylmercury exposure. In Reviews of Environmental Contamination and Toxicology, Vol 198. New York: Springer; 2009:111-132.

7. United States Environmental Protection Agency: Mercury Study Report to Congress. Vol. 1: Executive Summary. Washington D.C: Government Printing Office; 1997. Report EPA-452/R-97-003.

8. Ekino S, Susa M, Ninomiya T, Imamura K, Kitamura T: Minamata disease revisited: An update on the acute and chronic manifestations of methyl mercury poisoning. J Neurol Sci 2007, 262(1-2):131-144.

9. Masazumi H: Congenital Minamata disease: Intrauterine methylmercury poisoning. Teratology 1978, 18(2):285-288.

10. Grandjean P, Weihe P, White RF, Debes F, Araki S, Yokoyama K, Murata K, Sorensen N, Dahl R, Jorgensen PJ: Cognitive deficit in 7-year-old children with prenatal exposure to methylmercury. Neurotoxicol Teratol 1997, 19(6):417-428.

11. Debes F, Budtz-Jorgensen E, Weihe P, White RF, Grandjean P: Impact of prenatal methylmercury exposure on neurobehavioral function at age 14 years. Neurotoxicol Teratol 2006, 28(5):536-547.
12. Monroe RK, Halvorsen SW: Mercury abolishes neurotrophic factor-stimulated Jak-STAT signaling in nerve cells by oxidative stress. Toxicol Sci 2006, 94(1):129-138.

13. Yin Z, Milatovic D, Aschner JL, Syversen T, Rocha JBT, Souza DO, Sidoryk M, Albrecht J, Aschner M: Methylmercury induces oxidative injury, alterations in permeability and glutamine transport in cultured astrocytes. Brain Res 2007, 1131(1):1-10.

14. Valko M, Morris $\mathrm{H}$, Cronin MT: Metals, toxicity and oxidative stress. Curr Med Chem 2005, 12(10):1161-1208.

15. Bonacker D, Stoiber T, Wang M, Bo?hm KJ, Prots I, Unger E, Thier R, Bolt HM, Degen $\mathrm{GH}$ : Genotoxicity of inorganic mercury salts based on disturbed microtubule function. Arch Toxicol 2004, 78(10):575-583.

16. Ferraro L, Tomasini MC, Tanganelli S, Mazza R, Coluccia A, Carratu MR, Gaetani S, Cuomo V, Antonelli T: Developmental exposure to methylmercury elicits early cell death in the cerebral cortex and longterm memory deficits in the rat. Int J Dev Neurosci 2009, 27(2):165-174.

17. Cambier S, Benard G, Mesmer-Dudons N, Gonzalez P, Rossignol R, Brethes $D$, Bourdineaud JP: At environmental doses, dietary methylmercury inhibits mitochondrial energy metabolism in skeletal muscles of the zebra fish (Danio rerio). Int J Biochem Cell Biol 2009, 41(4):791-799.

18. Konigsberg M, Lopez-Diazguerrero NE, Bucio L, Gutierrez-Ruiz MC: Uncoupling effect of mercuric chloride on mitochondria isolated from an hepatic cell line. J App/ Toxicol 2001, 21(4):323-329.

19. Burlando $\mathrm{B}$, Bonomo $\mathrm{M}$, Fabbri $\mathrm{E}$, Dondero $\mathrm{F}$, Viarengo $\mathrm{A}: \mathrm{Hg}^{2+}$ signaling in trout hepatoma (RTH-149) cells: Involvement of $\mathrm{Ca}^{2+}$-induced $\mathrm{Ca}^{2+}$ release. Cell Calcium 2003, 34(3):285-293.

20. Marty SM, Atchison WD: Pathways mediating $\mathrm{Ca}^{2+}$ entry in rat cerebellar granule cells following in vitro exposure to methyl mercury. Toxicol App/ Pharmacol 1997, 147(2):319-330.

21. Jin YH, Dunlap PE, McBride SJ, Al-Refai H, Bushel PR, Freedman JH: Global transcriptome and deletome profiles of yeast exposed to transition metals. PLoS Genet 2008, 4(4):e1000053.

22. Ung CY, Lam SH, Hlaing MM, Winata CL, Korzh S, Mathavan S, Gong Z: Mercury-induced hepatotoxicity in zebrafish: In vivo mechanistic insights from transcriptome analysis, phenotype anchoring and targeted gene expression validation. BMC Genomics 2010, 11:212.

23. Yu XZ, Robinson JF, Sidhu JS, Hong S, Faustman EM: A system-based comparison of gene expression reveals alterations in oxidative stress, disruption of ubiquitin-proteasome system and altered cell cycle regulation after exposure to cadmium and methylmercury in mouse embryonic fibroblast. Toxicol Sci 2010, 114(2):356-377.

24. Clarkson TW, Magos L: The toxicology of mercury and its chemical compounds. Crit Rev Toxicol 2006, 36(8):609-662.

25. Freitas AJ, Rocha JB, Wolosker $\mathrm{H}$, Souza DO: Effects of $\mathrm{Hg}^{2+}$ and $\mathrm{CH}_{3} \mathrm{Hg}^{+}$ on $\mathrm{Ca}^{2+}$ fluxes in rat brain microsomes. Brain Res 1996, 738(2):257-264.

26. Gardner RM, Nyland JF, Silbergeld EK: Differential immunotoxic effects of inorganic and organic mercury species in vitro. Toxicol Lett 2010, 198(2):182-190.

27. Gasso S, Sunol C, Sanfeliu C, Rodriguez-Farre E, Cristofol RM: Pharmacological characterization of the effects of methylmercury and mercuric chloride on spontaneous noradrenaline release from rat hippocampal slices. Life Sci 2000, 67(10):1219-1231.

28. McElwee MK, Freedman JH: Comparative toxicology of mercurials in Caenorhabditis elegans. Environ Toxicol Chem 2011, 30(9):2135-2141.

29. Chou JW, Zhou T, Kaufmann WK, Paules RS, Bushel PR: Extracting gene expression patterns and identifying co-expressed genes from microarray data reveals biologically responsive processes. BMC Bioinformatics 2007, 8:427.

30. Liang $\mathrm{GH}$, Jarlebark $\mathrm{L}$, Ulfendahl M, Moore EJ: Mercury $\left(\mathrm{Hg}^{2+}\right)$ suppression of potassium currents of outer hair cells. Neurotoxicol Teratol 2003, 25 (3):349-359.

31. Yuan Y, Otero-Montanez JKL, Yao A, Herden CJ, Sirois JE, Atchison WD: Inwardly rectifying and voltage-gated outward potassium channels exhibit low sensitivity to methylmercury. Neurotoxicology 2005, 26(3):439-454

32. Hasegawa $\mathrm{K}$, Omata $\mathrm{S}$, Sugano $\mathrm{H}$ : In vivo and in vitro effects of methylmercury on the activities of aminoacyl-tRNA synthetases in rat brain. Arch Toxicol 1988, 62(6):470-472.

33. Doyle LA, Ross DD: Multidrug resistance mediated by the breast cancer resistance protein BCRP (ABCG2). Oncogene 2003, 22(47 REV. ISS. 6):7340-7358. 
34. Willem $M$, Lammich $S$, Haass C: Function, regulation and therapeutic properties of $\beta$-secretase (BACE1). Semin Cell Dev Biol 2009, 20(2):175-182

35. Li Z, Vance DE: Phosphatidylcholine and choline homeostasis. $J$ Lipid Res 2008, 49(6):1187-1194

36. Guillou H, Zadravec D, Martin PGP, Jacobsson A: The key roles of elongases and desaturases in mammalian fatty acid metabolism: Insights from transgenic mice. Prog Lipid Res 2010, 49(2):186-199.

37. Lu SC: Regulation of glutathione synthesis. Mol Aspects Med 2009, 30(1-2):42-59.

38. Cuzzocrea S, Wang ZQ: Role of poly(ADP-ribose) glycohydrolase (PARG) in shock, ischemia and reperfusion. Pharmacol Res 2005, 52(1 SPEC. ISS):100-108.

39. Robinson JF, Griffith WC, Yu XZ, Hong S, Kim E, Faustman EM: Methylmercury induced toxicogenomic response in C57 and SWV mouse embryos undergoing neural tube closure. Reprod Toxicol 2010, 30(2):284-291

40. Liu J, Lei D, Waalkes MP, Beliles RP, Morgan DL: Genomic analysis of the rat lung following eemental mercury vapor exposure. Toxicol Sci 2003, 74(1):174-181.

41. Kramer KK, Liu J, Choudhuri S, Klaassen CD: Induction of metallothionein mRNA and protein in murine astrocyte cultures. Toxicol Appl Pharmacol 1996, 136(1):94-100.

42. Klaper R, Carter BJ, Richter CA, Drevnick PE, Sandheinrich MB, Tillitt DE: Use of a $15 \mathrm{k}$ gene microarray to determine gene expression changes in response to acute and chronic methylmercury exposure in the fathead minnow Pimephales promelas Rafinesque. J Fish Biol 2008, 72(9):2207-2280.

43. Yasutake A, Nakano A, Hirayama K: Induction by mercury compounds of brain metallothionein in rats: $\mathrm{Hg}^{0}$ exposure induces long-lived brain metallothionein. Arch Toxicol 1998, 72(4):187-191.

44. Gonzalez P, Dominique Y, Massabuau JC, Boudou A, Bourdineaud JP Comparative effects of dietary methylmercury on gene expression in liver, skeletal muscle, and brain of the zebrafish (Danio rerio). Environ Sci Technol 2005, 39(11):3972-3980.

45. Chen RW, Ganther HE, Hoekstra WG: Studies on the binding of methylmercury by thionein. Biochem Biophys Res Commun 1973, 51(2):383-390.

46. Leiva-Presa A, Capdevila M, Cols N, Atrian S, Gonzalez-Duarte P: Chemical foundation of the attenuation of methylmercury(II) cytotoxicity by metallothioneins. Eur J Biochem 2004, 271(7):1323-1328.

47. Yao CP, Allen JW, Conklin DR, Aschner M: Transfection and overexpression of metallothionein-I in neonatal rat primary astrocyte cultures and in astrocytoma cells increases their resistance to methylmercury-induced cytotoxicity. Brain Res 1999, 818(2):414-420.

48. D'Amours D, Desnoyers S, D'Silva I, Poirier GG: Poly(ADP-ribosyl)ation reactions in the regulation of nuclear functions. Biochem J 1999, 342(2):249-268.

49. Fauzee NJ, Pan J, Wang YL: PARP and PARG inhibitors-new therapeutic targets in cancer treatment. Pathol Oncol Res 2010, 16(4):469-478.

50. Sakaue M, Mori N, Okazaki M, Ishii M, Inagaki Y, lino Y, Miyahara K, Yamamoto M, Kumagai T, Hara S, et al: Involvement of independent mechanism upon Poly (ADP-ribose) Polymerase (PARP) activation in methylmercury cytotoxicity in rat cerebellar granule cell culture. J Neurosci Res 2008, 86(15):3427-3434.

51. WormBase; 2011. web site, http://www.wormbase.org: Release WS221.

52. Kniazeva M, Crawford QT, Seiber M, Wang CY, Han M: Monomethyl branched-chain fatty acids play an essential role in Caenorhabditis elegans development. PLOS Biol 2004, 2(9):1446-1459.

53. Strain JJ, Davidson PW, Bonham MP, Duffy EM, Stokes-Riner A, Thurston SW, Wallace JMW, Robson PJ, Shamlaye CF, Georger LA, et al: Associations of maternal long-chain polyunsaturated fatty acids, methyl mercury, and infant development in the Seychelles Child Development Nutrition Study. Neurotoxicology 2008, 29(5):776-782.

54. Choi AL, Cordier S, Weihe P, Grandjean P: Negative confounding in the evaluation of toxicity: The case of methylmercury in fish and seafood. Crit Rev Toxicol 2008, 38(10):877-893.

55. Naganuma A, Furuchi T, Miura N, Hwang G-W, Kuge S: Investigation of intracellular factors involved in methylmercury toxicity. Tohoku J Exp Med 2002, 196(2):65-70

56. Hwang GW, Sasaki D, Naganuma A: Overexpression of Rad23 confers resistance to methylmercury in Saccharomyces cerevisiae via inhibition of the degradation of ubiquitinated proteins. Mol Pharmacol 2005, 68(4):1074-1078
57. Famulski JK, Trivedi N, Howell D, Yang Y, Tong Y, Gilbertson R, Solecki DJ: Siah regulation of Pard $3 \mathrm{~A}$ controls neuronal cell adhesion during germinal zone exit. Science 2010, 330(6012):1834-1838.

58. Harada M: Minamata disease: Methylmercury poisoning in Japan caused by environmental pollution. Crit Rev Toxicol 1995, 25(1):1-24.

59. Choi BH: The effects of methylmercury on the developing brain. Prog Neurobiol 1989, 32(6):447-470.

60. Williams PL, Dusenbery DB: Using the nematode Caenorhabditis elegans to predict mammalian acute lethality to metallic salts. Toxicol Ind Health 1988, 4(4):469-478

61. Sulston J, Hodgkin J: Methods. In The Nematode Caenorhabditis elegans. Edited by Wood WB. Cold Spring Harbor, NY: Cold Spring Harbor Laboratory Press; 1988:587-606.

62. Liao VH, Freedman JH: Cadmium-regulated genes from the nematode Caenorhabditis elegans. Identification and cloning of new cadmiumresponsive genes by differential display. J Biol Chem 1998, 273(48):31962-31970.

63. Zheng Y, Li XK, Wang Y, Cai L: The role of zinc, copper and iron in the pathogenesis of diabetes and diabetic complications: Therapeutic effects by chelators. Hemoglobin 2008, 32(1-2):135-145.

64. Kamath RS, Fraser AG, Dong Y, Poulin G, Durbin R, Gotta M, Kanapin A, Le Bot N, Moreno S, Sohrmann M, et al: Systematic functional analysis of the Caenorhabditis elegans genome using RNAi. Nature 2003, 421(6920):231-237.

65. Rual JF, Ceron J, Koreth J, Hao T, Nicot AS, Hirozane-Kishikawa T, Vandenhaute J, Orkin SH, Hill DE, van den Heuvel S, et al: Toward improving Caenorhabditis elegans phenome mapping with an ORFeomebased RNAi library. Genome Res 2004, 14(10B):2162-2168.

66. Simmer F, Tijsterman M, Parrish S, Koushika SP, Nonet ML, Fire A, Ahringer J, Plasterk RH: Loss of the putative RNA-directed RNA polymerase RRF-3 makes C. elegans hypersensitive to RNAi. Curr Biol 2002, 12(15):1317-1319.

67. Boyd WA, Smith MV, Kissling GE, Rice JR, Snyder DW, Portier CJ, Freedman $\mathrm{JH}$ : Application of a mathematical model to describe the effects of chlorpyrifos on Caenorhabditis elegans development. PLOS One 2009, 4(9):e7024.

68. Mattie MD, Freedman JH: Protective effects of aspirin and vitamin E (alpha-tocopherol) against copper- and cadmium-induced toxicity. Biochem Biophys Res Commun 2001, 285(4):921-925.

69. Song MO, Li J, Freedman JH: Physiological and toxicological transcriptome changes in HepG2 cells exposed to copper. Physiol Genomics 2009, 38(3):386-401.

70. Livak KJ, Schmittgen TD: Analysis of relative gene expression data using real-time quantitative PCR and the $2^{-\Delta \Delta C} T$ Method. Methods (Duluth) 2001, 25(4):402-408

71. Rozen S, Skaletsky H: Primer3 on the WWW for general users and for biologist programmers. Methods Mol Biol 2000, 132:365-386

doi:10.1186/1471-2164-14-698

Cite this article as: McElwee et al:: Comparative toxicogenomic responses of mercuric and methyl-mercury. BMC Genomics 2013 14:698.

\section{Submit your next manuscript to BioMed Central and take full advantage of:}

- Convenient online submission

- Thorough peer review

- No space constraints or color figure charges

- Immediate publication on acceptance

- Inclusion in PubMed, CAS, Scopus and Google Scholar

- Research which is freely available for redistribution

Submit your manuscript at www.biomedcentral.com/submit
C) Biomed Central 